\title{
Severo Ochoa and the Biomedical Sciences in Spain under Franco, 1959-1975
}

\author{
By María Jesús Santesmases*
}

\begin{abstract}
The influence of Severo Ochoa in the establishment of biochemistry and molecular biology in Spain is the central topic of this essay. From the time he was awarded the Nobel Prize in Physiology or Medicine in 1959, Ochoa's links with Spanish scientists and top authorities in education and science became instrumental to the development of these areas in the country of his birth. Ochoa's influence is analyzed through investigation of three "events": the reception of the award in Spain and some of its immediate consequences; his role in the VIth Meeting of the Federation of European Biochemical Societies, held in Madrid in 1969; and the international scientific symposium, held in Madrid and Barcelona, that celebrated his seventieth birthday in 1975. After an account of Ochoa's biography up to 1959, analysis of these events shows that Ochoa's influence cannot be understood without taking into account the political and scientific context of its reception.
\end{abstract}

$\Upsilon^{H}$ ESTABLISHMENT OF BIOCHEMISTRY AND MOLECULAR BIOLOGY as fields of research in Spain from the early 1960s onward could scarcely be understood without taking into account the role played by Severo Ochoa. The Nobel Prize in Physiology or Medicine awarded to him in 1959, though based on his work with Marianne Grunberg-Manago on polynucleotide phosphorylase (PNPase), might well be regarded as a recognition of almost twenty years of work in enzymology. Ochoa's own research trajectory mirrored that of his field: the physiological origins of biochemistry, its development

* Unidad de Políticas Comparadas, Consejo Superior de Investigaciones Científicas, Alfonso XII, 18, 28014 Madrid, Spain.

I am gratefully indebted to Luís Cornudella, Ricardo Díez-Hochleitner, Emilio Muñoz, Juan Oró, Jaume Palau, and Margarita Salas for useful information on events discussed in this essay. I also acknowledge the family of Alberto Sols for permission to consult the Alberto Sols Papers; Frances Thompson-Grisolía for her help in consulting the Severo Ochoa Papers at the Fundación Valenciana de Investigaciones Citológicas; the Spanish Society of Biochemistry for providing documents on its meetings; Margarita Salas and Charo Martín for help in consulting the archives of the Centro de Biología Molecular Severo Ochoa in Madrid; Ángel Martín Municio for donating the papers of the Spanish delegation at the European Conference of Molecular Biology; and the personnel of the Hemeroteca Nacional at the Biblioteca Nacional, Madrid. Useful comments on a previous draft of this essay were offered by Pnina Abir-Am, Angela Creager, Soraya de Chadarevian, and the three anonymous referees for Isis.

On the history of molecular biology, I would like to stress my deep appreciation for the work of Lily E. Kay, which has been a source of inspiration and encouragement for me. Her sudden recent death deprives us of the work of an incisive and stimulating scholar. 
from the interwar period, and its role in the influential developments in molecular biology from the $1950 \mathrm{~s}$ on. As a prominent scientist alert to the opportunities provided by the growing interest in nucleic acid, Ochoa sought to keep enzymology at the core of biomedical developments in the postwar period. His emphasis on the primacy of enzymes helped define the promise of contemporary molecular biology and, more broadly, biomedicine; polymerases and, later, restriction enzymes played an increasing role as both the tools and the objects of inquiry in genetic engineering. ${ }^{1}$

This essay discusses Ochoa's contributions to the consolidation of biochemistry and molecular biology as scientific disciplines in Spain. I consider biochemistry and molecular biology together. They were established in Spain as closely related disciplines-both cognitively and institutionally — although biochemistry was introduced slightly earlier. As a result, biochemistry contributed to the delineation of molecular biology even as the two fields were differentiated somewhat. The rhetoric that kept them separated in research centers in other countries - where the distinction was often drawn by the most influential of the self-described molecular biologists - was to some extent circumvented in Spain by Ochoa's particular scientific trajectory. ${ }^{2}$ International recognition, which came first, drew attention to the work of young Spanish researchers who were trying to build careers. Ochoa served as a particularly influential agent of recognition. As a distinguished representative of research done in the United States by a Spanish-born scientist-he obtained U.S. citi-

' Susan Wright, Molecular Politics: Developing American and British Regulatory Policy for Genetic Engineering, 1972-1982 (Chicago: Univ. Chicago Press, 1994). On molecular biology and biochemistry see María Jesús Santesmases and Emilio Muñoz, "Scientific Organizations in Spain: Social Isolation and International Legitimation of Biochemists and Molecular Biologists on the Periphery," Social Studies of Science, 1997, 27:187-219 (hereafter cited as Santesmases and Muñoz, "Scientific Organizations in Spain"); the contributions to Soraya de Chadarevian and Jean-Paul Gaudilliére, eds., The Tools of the Discipline: Biochemists and Molecular Biologists, Journal of the History of Biology, 1996, 29(3), by Angela Creager, Chadarevian, HansJörg Rheinberger, and Gaudilliére; and Pnina G. Abir-Am, "The Politics of Macromolecules: Molecular Biologists, Biochemists, and Rhetoric," Osiris, 2nd Ser., 1992, 7:164-191. Some of the books cited here have been reviewed in Abir-Am, "New Trends in the History of Molecular Biology," Historical Studies in the Physical and Biological Sciences, 1995, 25:167-193. On the history of molecular biology see Michel Morange, Histoire de la biologie moléculaire (Paris: La Découverte, 1994); Lily E. Kay, The Molecular Vision of Life: CalTech, the Rockefeller Foundation, and the Rise of the New Biology (Oxford/New York: Oxford Univ. Press, 1993); Rheinberger, Toward a History of Epistemic Things: Synthesizing Proteins in the Test Tube (Stanford, Calif.: Stanford Univ. Press, 1997); Abir-Am, "From Multidisciplinary Collaboration to Transnational Objectivity: International Space as Constitutive of Molecular Biology," in Denationalizing Science, ed. Elisabeth Crawford, Terry Shinn, and S. Sörlin (Dordrecht: Kluwer, 1992), pp. 153-186; Robert E. Kohler, Partners in Science: Foundations and Natural Scientists, 1900-1945 (Chicago: Univ. Chicago Press, 1991); Robert Olby, "The Molecular Revolution in Biology," in A Companion to History of Science, ed. Olby, G. N. Cantor, J. R. R. Christie, and M. J. S. Hodge (London/New York: Routledge, 1990), pp. 503-520; Thomas D. Brock, The Emergence of Bacterial Genetics (Cold Spring Harbor, N.Y.: Cold Spring Harbor Laboratory Press, 1990); Edward Yoxen, "Giving Life a New Meaning: The Rise of the Molecular Biology Establishment," in Scientific Establishment and Hierarchies, ed. Norbert Elias, Herminio Martins, and Richard Whitley (Sociology of the Sciences Yearbook, 6) (Dordrecht: Reidel, 1982), pp. 123-143; Horace Judson, The Eighth Day of Creation (New York: Simon \& Schuster, 1979); and Olby, The Path to the Double Helix (London: Macmillan, 1974).

${ }^{2}$ See María Jesús Santesmases and Emilio Muñoz, "The Scientific Periphery in Spain: The Establishment of a Biomedical Discipline at the Centro de Investigaciones Biológicas," Minerva, 1997, 35:27-45; Santesmases and Muñoz, "Scientific Organizations in Spain"; and Chadarevian and Gaudilliére, eds., Tools of the Discipline. Eventually, the path to molecular biology through biochemistry would become a tradition; many years later the well-known molecular biologist David Baltimore described himself as "coming from the biochemical tradition pioneered by Severo Ochoa and Arthur Kornberg": David Baltimore, "In Memoriam: Howard Temin, the Fierce Scholar," in DNA: The Double Helix: Perspective and Prospective at Forty Years, Annals of the New York Academy of Sciences, 1995, 758:166-170, on p. 167. I will treat disciplinary discourses and shifts while exploring the local and international factors that contributed to the establishment of biochemistry and molecular biology in Spain. 
zenship in the 1950s - he inspired both scientists and science policy makers in his native country, for it was immediately after receiving the Nobel award that he began to serve as an official advisor for both groups. Ochoa's inspiration and support came at a particularly opportune moment.

The conditions for scientific development in Spain were shaped by the circumstances of the Civil War (1936-1939) and the dictatorship established in its aftermath. General Francisco Franco, supreme commander of the rebel army that initiated the war against the Spanish Republic, was the self-appointed head of the government from 1939 until his death in 1975. The war interrupted a trend of Spanish scientists' increasing involvement in the experimental biomedical sciences during the first decades of the twentieth century, a promising period in which new laboratories devoted to physiology were created in Madrid and Barcelona and the importance of bacteriology — with its investigations of vaccines and serum production - to public health was recognized. With the war, many of Spain's most prominent scientists went into exile; others were purged for ideological reasons. The first decade of Francoism, which one Spanish writer has called a "time of silence," was the hardest period of the dictatorship. ${ }^{3}$

Nonetheless, even in the period when Spain - and, consequently, Spanish sciencewas most isolated, during the 1940s, international contacts did not cease. A new council for scientific research, the Consejo Superior de Investigaciones Científicas (CSIC), was created by the Franco government in 1939. In the late 1940s CSIC authorities saw to it that a few of the most promising young scientists spent short training periods abroad. This research training policy, facilitated by the personal relationships established by top scientists in the CSIC, catalyzed the emergence of new scientific interests and experimental approaches not only in biochemistry but in physiology, endocrinology, and microbiology as well. The CSIC also played a key role by supporting these investigators when they returned to Spain, providing a home for their research in the years before the universities recognized the new disciplines by creating professorial chairs. ${ }^{4}$

These Spanish researchers, then, were aware of and interested in the new biochemical knowledge being pursued in scientific centers in Great Britain, Germany, Switzerland, the Netherlands, and the United States. In particular, they were familiar with the work of Severo Ochoa-which was beginning to obtain recognition from the elite members of the field. When Ochoa was awarded the Nobel Prize in 1959, the young Spanish biochemical researchers and their protégés not only celebrated the significance of his work but took the opportunity to emphasize the broader role played by biochemistry and molecular biology in the production of biomedical knowledge. From this date, discourse favorable to

\footnotetext{
${ }^{3}$ Luis Martín Santos, Tiempo de silencio (Barcelona: Seix-Barral, 1961), is a famous novel about the life and thought of a young medical researcher in Madrid during the 1940s. On the situation in the early decades of the twentieth century see Josep-Lluis Barona, La doctrina y el laboratorio: Fisiología y experimentación en la sociedad española des siglo XIX (Madrid: CSIC, 1992); and Antoni Roca and Thomas F. Glick, Francesc Duran $i$ Reynals (1899-1958) (Barcelona: Ajuntament de Barcelona, 1985). On the fate of scientists during and after the Civil War see María Jesús Santesmases, "El legado de Cajal frente a Albareda: Las ciencias biológicas en los primeros años del CSIC y los orígenes del CIB," Arbor, 1998, nos. 631-632, pp. 305-332; and Santiago López, "La investigación científica y técnica antes y después de la guerra civil," in Economía y sociedad en la España moderna y contemporánea, ed. Antonio Gómez Mendoza (Madrid: Síntesis, 1996), pp. 265-275. For a recent account of Spanish science and technology policy see Luis Sanz-Menéndez, Estado, ciencia y tecnología en España: 1939-1997 (Madrid: Alianza, 1997).

${ }^{4}$ See Santesmases, "Legado de Cajal”; and Pedro González Blasco and José Jiménez Blanco, "Tres estudios sobre la ciencia en España," in Historia y sociologia de la ciencia en España, ed. González Blasco, Jiménez Blanco, and José María López Piñero (Madrid: Alianza, 1979), pp. 95-195.
} 
biochemical approaches began to spread and become influential among medical and biological researchers and science policy makers in Spain. ${ }^{5}$

At the same time, other conditions were changing as well. During the 1950s Spain began to rebuild its international relationships, departing from the autarky that had characterized the early years of Franco's rule. In 1959 new economic measures were put into force, with far-reaching consequences for Spanish science. ${ }^{6}$

This essay argues that a combination of national and international influences - the Nobel award to a Spanish-born scientist, a receptive research community, and a government increasingly inclined to reassert itself on the international stage-together facilitated a special emphasis on biochemistry and molecular biology in the reconstruction of Spanish science after $1959 .{ }^{7}$ I begin with a brief description of Severo Ochoa's scientific achievements prior to his reception of the Nobel Prize. Then I analyze three "events" related to his research that influenced the emerging Spanish community of biochemists and molecular biologists. The first is the notice accorded Ochoa's Nobel Prize in the country of his birth and some of its immediate consequences, such as celebratory publications, national conferences on biochemistry, and the creation of the Sociedad Española de Bioquímica. The second is an international meeting on biochemistry held in Madrid in 1969, following the deciphering of the genetic code-work to which Ochoa made a key contribution. The third is the International Symposium on Enzymatic Mechanisms in Biosynthesis and Cell Function, held in Barcelona and Madrid in 1975, after Ochoa retired from the New York University School of Medicine, to honor him on his seventieth birthday.

Linked by the presence and influence of a singular scientific leader, these celebrations and commemorations illuminate Ochoa's role in advancing Spanish science to the present day. ${ }^{8}$ Though the influence of this distinguished actor should not be minimized, it was not the only factor at work. Analysis of almost two decades of research, training, and policymaking practices in Spanish biomedicine reveals a complicated series of agendas; Ochoa's influence cannot be understood without considering the political and scientific context of its reception.

\section{SEVERO OCHOA: FROM PHYSIOLOGY TO POLYNUCLEOTIDES}

From the early days of biochemistry at the end of the eighteenth century (and well before the term "biochemistry" was used), its central problem was to determine the stages by which foodstuffs are broken down in the animal body. Further work to elucidate the

\footnotetext{
${ }^{5}$ On the active transformation of biochemical knowledge through contributions to enzymatic regulation see María Jesús Santesmases, "From Intestine Transport to Enzymatic Regulation: The Work of the Spanish Biochemist Alberto Sols," Studies in History and Philosophy of Biological and Biomedical Sciences, 2000, 31:287313.

${ }^{6}$ On the history of economics during Francoism see, e.g., Gabriel Tortella, El desarrollo de la España contemporánea; Historia económica de los siglos XIX y XX (Madrid: Alianza, 1994). For a review of early Francoism in particular see José Luis García Delgado, "La industrialización y el desarrollo económico de España durante el franquismo," in La economía española en el siglo XX; Una perspectiva histórica, ed. Jordi Nadal, Albert Carreras, and Carles Sudriá (Barcelona: Ariel, 1987), pp. 164-189; and Fernando Guirao, Spain and the Reconstruction of Western Europe, 1945-1957 (London: Macmillan, 1998).

${ }^{7}$ See Robert E. Kohler, From Medical Chemistry to Biochemistry: The Making of a Biomedical Discipline (Cambridge: Cambridge Univ. Press, 1982).

${ }^{8}$ On scientists' ceremonial occasions see Pnina G. Abir-Am and Clark A. Elliott, eds., Commemorative Practices in Science: Historical Perspectives on the Policy of Collective Memory, Osiris, 2000, 14; Abir-Am, "A Historical Ethnography of a Scientific Anniversary in Molecular Biology: The First Protein X-ray Photograph (1948, 1934)," Social Epistemology, 1992, 6:323-354; and Abir-Am, "How Scientists View Their Heroes: Some Remarks on the Mechanism of Myth Construction," J. Hist. Biol., 1982, 15:281-315.
} 
components of foodstuffs and on their respiratory and anaerobic oxidation enabled physiologists from the mid-nineteenth century onward to infer that oxidation might occur by a series of steps. The discovery of cell-free fermentation, attributable to the action of a ferment - or enzyme - as catalyst, encouraged further research on metabolism from the end of the nineteenth century. Fragmented knowledge about methods and types of mechanisms would be unified as the workings of specific cycles in which those smaller molecules were involved within organisms and the animal body began to be postulated from the 1930s on. The role of the catalysts, or enzymes, would become a central research topic in the biochemical field of intermediary metabolism, with significant contributions from Hans Krebs, Carl and Gerty Cori, and many others-including Severo Ochoa. ${ }^{9}$

Ochoa was born in Luarca, a small town in the north of Spain, in 1905. His father, a lawyer and businessman, made his fortune in Puerto Rico. After his retirement he returned to Spain, established his family in Gijón (a town in the northern Asturias region), and died when Severo, his youngest son, was seven years old. ${ }^{10}$ Severo Ochoa grew up in Málaga (in the south of Spain) and in 1923 entered medical school at the University of Madrid. When he completed the second of the six years required for graduation, Juan Negrín, chairman of the Department of Physiology at the medical school, offered him the chance to do research in a laboratory he directed in the Junta para la Ampliación de Estudios, a kind of research council to which some laboratories in Madrid belonged. Negrín had been trained at the University of Leipzig, where he earned an M.D. and became a physiologist while working as a research assistant in the physiology institute of Theodor von Brücke. At the beginning of the Great War Negrín returned to Spain; circumstances in Germany were an "obstacle for his keeping on working," though he had been offered a post as Privatdozent in Leipzig on the basis of his experience in research and teaching. ${ }^{11}$

Ochoa's creatine studies under Negrín led to an interest in the chemistry of muscle contraction and in Otto Meyerhof's newly published work on phosphocreatine. In 1929 Ochoa joined Meyerhof's laboratory in Berlin-Dahlem, where Fritz Lipmann and David Nachmansohn were among his postdoctoral colleagues. Later that year Meyerhof moved to a new building in Heidelberg, where he was appointed director of the physiology institute. During this period Ochoa confirmed the ability of muscle to use sources of energy other than that coming from carbohydrate breakdown. In 1932 he went to the National Institute for Medical Research in London to work with Harold W. Dudley; there he did research on his "first enzyme problem, glyoxalase" from pancreatic extracts. After fourteen months he returned to Madrid to rejoin Negrín's laboratory; by this time he was already familiar with the literature on glycolysis and fermentation and decided to study glycolysis

\footnotetext{
${ }^{9}$ Frederic L. Holmes, Hans Krebs, Vol. 1: The Formation of a Scientific Life, 1900-1933 (New York: Oxford Univ. Press, 1991); Holmes, Hans Krebs, Vol. 2: Architect of Intermediary Metabolism (New York: Oxford Univ. Press, 1993); and Holmes, Between Biology and Medicine: The Formation of Intermediary Metabolism (Berkeley: Univ. California Press, 1992).

${ }^{10}$ On Severo Ochoa see his autobiography, "The Pursuit of a Hobby," Annual Review of Biochemistry, 1980, 49:1-30; Francisco Grande and Carlos Asensio, "Severo Ochoa and the Development of Biochemistry," in Reflections on Biochemistry: In Honour of Severo Ochoa, ed. A. Kornberg, B. L. Horecker, L. Cornudella, and J. Oró (Oxford/New York: Pergamon, 1976) (hereafter cited as Reflections on Biochemistry, ed. Kornberg et al.), pp. 1-14; and Grande, "Severo Ochoa," ICSU Review of World Science, 1963, 5:147-158. On Ochoa's family see Marino Gómez Santos, Severo Ochoa: La emoción de descubrir (Madrid: Pirámide, 1993), which is based on personal interviews with Ochoa and his Spanish colleagues and friends.

${ }^{11}$ On Negrín see Barona, Doctrina y el laboratorio (cit. n. 3), pp. 262-278. Negrín would be appointed minister of the Treasury in the Republican government in 1936, after the Civil War had already begun, and in 1937 he became prime minister. See Juan Marichal, "Juan Negrín: El clentífico como gobernante," in El intelectual y la política (Madrid: Residencia de Estudiantes, 1990), pp. 83-106.
} 
in heart muscle. After Ochoa defended his Ph.D. thesis - on the role of the adrenal glands in muscle contraction-in 1934, Carlos Jiménez Díaz, a clinician and professor at the University of Madrid medical school, offered him the directorship of the physiology section of his institute at the school. Ochoa began work there in 1935. With the start of the Civil War in 1936, however, he decided to leave Spain: "Clearly, to continue doing research without a long interruption that might forever destroy my chances of becoming a scientist, I would have to go elsewhere and, after much thought, my wife [Carmen Cobián] and I decided to leave Spain."12

Returning to Meyerhof's laboratory in Heidelberg, Ochoa worked on glycolysis in heart muscle, on the isolation of pure cozymase-the muscle fraction known to intervene in glycolysis - from skeletal muscle, and on transphosphorylation in muscle extracts. By this time the laboratory had turned to biochemistry: glycolysis and fermentation in muscle or yeast extract and partial reactions catalyzed by purified enzymes were the main subjects of investigation. In 1937, with Germany under the control of the Nazis, Meyerhof left for Paris. He arranged a six-month fellowship for Ochoa at the Marine Biological Laboratory in Plymouth (U.K.); from there Ochoa moved on to the Oxford biochemistry department to work with Rudolph A. Peters on the role of vitamin B1 (thiamine) and cocarboxylase (pyrophosphate ester of thiamine) in pyruvate oxidation. The work was very productive: they established that cocarboxylase, rather than thiamine, was the cofactor for pyruvate oxidation in pigeon brain and showed a requirement for adenine nucleotides that suggested a coupling of oxidation and phosphorylation. But once more a period of promising work was cut short, this time by World War II: Peters's whole lab became involved in war work, and Ochoa, as a foreigner, had to leave. ${ }^{13}$

In August 1940 Ochoa left Europe. By this time, his investigative move from physiology to biochemistry had already taken place. In addition to his work under Meyerhof on the energetics of muscular contraction, Ochoa had explored the role of the adrenal glands in 1932-1933, when he joined Dudley in London. He had moved on to glycolysis and fermentation in heart muscle when he returned to Madrid before the outbreak of the Civil War and had continued this work in Berlin, in addition to transphosphorylation studies on muscle extracts. Working with brain homogenates in Oxford, he had found "that the oxidation of pyruvate in brain homogenates, in the presence of catalytic amounts of AMP or ATP, was coupled with the phosphorylation of hexosemonophosphate or glucose." 14

In 1940, after some weeks in Mexico City, Ochoa joined Carl Cori at his laboratory at the Washington University School of Medicine in St. Louis, where he hoped to contribute to the enzyme and phosphorylase research of the group. Herman Kalckar, Earl Sutherland, and Sidney Colowick were also at Washington. Unfortunately, all Ochoa's efforts to show, as Cori proposed, "that fructose-1-phosphate would be converted to fructose-6-phosphate, either of which would then form glucose-6-phosphate, were in vain. To make matters worse there was a rather large accumulation of inorganic pyrophosphate along with fructose-1-phosphate. I left the Cori laboratory a bit frustrated having explained nothing."15 He had, however, learned a great deal about the practice of enzymology.

\footnotetext{
${ }^{12}$ Ochoa, "Pursuit of a Hobby" (cit. n. 10), pp. 7, 8. On Ochoa's scientific trajectory see, in addition to his autobiography, Marianne Grunberg-Manago, "Severo Ochoa," Biographical Memoirs of the Fellows of the Royal Society of London, 1997, 43:349-365; the work with Meyerhof is discussed on p. 352. For a publication with Dudley see Severo Ochoa and Harold W. Dudley, "The Antiglyoxalase Action of Pancreatic Extracts and Related Experiments on the Inhibition of Glycolisis in Muscle Extracts," Chemistry and Industry, 1933, 52:421.

${ }^{13}$ Ochoa, "Pursuit of a Hobby," p. 9.

${ }_{14}$ Ibid., p. 13.

${ }^{15}$ Ibid., p. 10.
} 
In 1942 Ochoa moved to New York University as a research associate in medicine, thanks to the support of NYU nutritionist Bob Goodhart, whom Ochoa had met during his stay in Peters's laboratory in Oxford. It would be at NYU, where he worked until his retirement, that Ochoa produced most of his scientific work that contributed to the development of biochemistry and, subsequently, to the deciphering of the genetic code. Ochoa began by returning to the problem of oxidative phosphorylation - a mechanism whereby energy is made available from biological oxidation - on which he had first worked at Oxford. He concluded in 1943 that the atomic ratio of phosphorus esterified to oxygen consumed (P/O ratio) of pyruvate oxidation was 3, a finding later confirmed by Albert L. Lehninger using mitochondria. Building on his earlier research in Europe, Ochoa resumed his studies of transphosphorylation and consumption of oxygen, this time in heart homogenates. Interest in Hans Krebs's proposal of a citric acid cycle as the main pathway for the oxidation of foodstuffs led Ochoa to study the enzymes involved. ${ }^{16}$

In 1946 Ochoa was appointed chairman of the NYU Department of Pharmacology at the suggestion of the English biophysicist Keith Cannan, the chairman of the Department of Biochemistry where Ochoa had had a laboratory space. Ochoa was only the second biochemist to be named a professor of pharmacology - "since Cori was the first I was in good company." He succeeded James A. Shannon, who had just been invited to join the National Institutes of Health. ${ }^{17}$ In 1954 Ochoa moved to the chair of the Department of Biochemistry. During the intervening years he worked on the citric acid cycle and related metabolic pathways. It has been said that "he adopted a clearly enzymological approach. Since each step of the process should be catalyzed by a specific enzyme, one must isolate each enzyme in order to clarify the mechanism. Some of the enzymes were already known, but none had been isolated to a sufficient degree of purity." Ochoa's research on intermediary metabolism-including pyruvic acid oxidation, the reversible conversion of oxaloacetate into citrate, the formation of oxalosuccinate and alpha-ketoglutarate, the oxidation of alpha-ketoglutarate and the malic enzyme - brought him into prominence among the core enzymologists. ${ }^{18} \mathrm{He}$ also conducted research on fatty acid metabolism through the metabolism of propionic acid and investigated topics in photosynthesis as they related to the light dependence of reductive carboxylation of pyruvate to malate. ${ }^{19}$

\footnotetext{
${ }^{16}$ Severo Ochoa, "Efficiency of Aerobic Phosphorylation in Cell-Free Heart Extracts," Journal of Biological Chemistry, 1943, 151:493-505; and Lars Ernster, "P/O Ratios-The First Fifty Years," FASEB Journal, 1993, 7:1520-1524. For Ochoa's own view of his work during this period see Ochoa, "Pursuit of a Hobby," pp. 814.

${ }^{17}$ Ochoa, "Pursuit of a Hobby," p. 11. He noted, "Cannan had the idea that I, having had a medical training, might be fit for the job of Chairman of that department" (ibid.). Shannon would be director of the NIH from 1955 to 1968. See Thomas J. Kennedy, Jr., "James Augustine Shannon," Biog. Mem. Fellows Nat. Acad. Sci. (www.nap.edu/readingroom/books/biomems/jshannon). See also Sarah Ratner, "A Long View of Nitrogen Metabolism," Ann. Rev. Biochem., 1997, 46:1-24; and James A. Shannon, "The National Institutes of Health: Some Critical Years, 1955-1957," Science, 1987, 237:865-868.

${ }^{18}$ Grande and Asensio, "Ochoa and the Development of Biochemistry" (cit. n. 10), p. 4. For examples of articles on each of these topics see S. Korkes, A. del Campillo, I. C. Gonsalus, and S. Ochoa, "Enzymatic Synthesis of Citric Acid, IV: Pyruvate as Acetyl Donor," J. Biol. Chem., 1951, 193:721-735 (pyruvic acid oxidation); J. R. Stern, Ochoa, and F. Lynen, "Enzymatic Synthesis of Citric Acid, V: Reaction of Acetyl Coenzyme A," ibid., 1952, 198:313-321 (reversible conversion); Ochoa, "Biosynthesis of Tricarboxylic Acids by Carbon Dioxide Fixation, III: Enzymatic Mechanism," ibid., 1948, 174:133-157 (oxalosuccinate and alphaketoglutarate); S. Kauffman, C. Gilvarg, O. Cori, and Ochoa, "Enzymatic Oxidations of $\alpha$-Ketoglutarate and Coupled Phosphorylation," ibid., 1953, 203:869-888 (oxidation of alpha-ketoglutarate); and Ochoa, A. Mehler, and A. Kornberg, "Biosynthesis of Dicarboxylic Acids by Carbon Dioxide Fixation, I: Isolation and Properties of an Eyzyme from Pigeon Liver Catalyzing the Reversible Oxidative Decarboxylation of $l$-Malic Acid," ibid., 1948, 174:979-1000 (oxidation of the malic enzyme).
}

${ }^{19}$ The work on fatty acid metabolism is reviewed in Yoshito Kaziro and Severo Ochoa, "The Metabolism of 
Enzymological questions also prompted the identification of the new polymerization enzyme polynucleotide phosphorylase in Ochoa's lab-work accomplished by his French postdoctoral fellow Marianne Grunberg-Manago when studying the mechanism of oxidative phosphorylation in extracts of the highly aerobic bacteria Azobacter vinelandii. We know from Grunberg-Manago's account of her work on this problem that, at Ochoa's suggestion, she was trying to isolate a system for ATP synthesis linked to oxidation. She decided to investigate the exchange reaction between phosphate and ATP in A. vinelandii and tried to isolate "interesting new coenzymes." She realized, however, that the ADP impurity of the amorphous ATP was the active component of phosphate exchange. A few months later Grunberg-Manago noted that she was dealing not only with an exchange reaction but with a reaction in which active phosphate was liberated; its product was a high-molecular-weight compound that she identified as a polynucleotide. The product was characterized with the help of Leon Heppel, Jacques Fresco, and Alexander Rich, and Grunberg-Manago was able to synthesize ribonucleic acids very similar to biological RNA. Grunberg-Manago and Ochoa described the reversible reaction catalyzed by PNPase as

$$
\mathrm{n} \mathrm{X-R-P-P} \rightleftarrows \mathrm{n}(\mathrm{X}-\mathrm{R}-\mathrm{P})+\mathrm{n} \mathrm{P}
$$

where R stands for ribose; X may be adenine, hypoxanthine, guanine, uracil, or cytosine; and $\mathrm{P}$ is the phosphate group. This was the first time that a polyribonucleotide was produced in a test tube, and the work attracted considerable attention. ${ }^{20}$

The first results were presented at the meeting of the Federation of Societies of Experimental Biology held in San Francisco in 1955 and published by Grunberg-Manago and Ochoa later the same year in the Journal of the American Chemical Society. Ochoa continued to seek evidence that the RNA-like polymers synthesized by the action of PNPase were biologically active RNA, but without success. In 1959 Ochoa and his former research fellow Arthur Kornberg shared the Nobel Prize "for their discovery of the mechanisms in the biological synthesis of ribonucleic acid [Ochoa] and deoxyribonucleic acid [Kornberg]."21

Questions pertaining to intermediary metabolism remained crucial to Ochoa's investigations. He and others thought polynucleotide phosphorylase was a new enzyme with new properties. Grunberg-Manago believed that Ochoa "was still hoping in the depth of his heart that the synthesized product had a pyrophosphate linkage and was involved in one way or another in oxidative phosphorylation." 22

Propionic Acid," Advances in Enzymology, 1964, 26:283-378; on investigations of light dependence see Wolf Vishniac and Ochoa, "Photochemical Reduction of Pyridine Nucleotides by Spinach Grana and Coupled Carbon Dioxide Fixation," Nature, 1951, 167:768-769.

${ }^{20}$ Marianne Grunberg-Manago, "Recollections on Studies of Polynucleotide Phosphorylase: A Commentary," Biochimica et Biophysica Acta, 1989, 1000:59-64; Grunberg-Manago, "Pleasure from PNPase," Current Contents, 1990, no. 15, pp. 20-21; and Grunberg Manago, "Severo Ochoa" (cit. n. 12), p. 360. I thank GrunbergManago for supplying me with copies of the first two papers.

${ }^{21}$ On the reception of the award in the scientific community see "Ochoa and Kornberg Win Nobel Prize," Science, 1959, 130:1099-1100; and "Nobel Prize for Medicine for 1959: Prof. S. Ochoa; Prof. A. Kornberg," Nature, 1959, 188:1021. See also Ochoa's reconstruction of the discovery in "Pursuit of a Hobby" (cit. n. 10), p. 19: "The first report was published as a Letter to the Editors of The Journal of the American Chemical Society [1955, 77:3165] despite very adverse criticism by a referee." On Kornberg's works see Arthur Kornberg, "For the Love of Enzymes," in Reflections on Biochemistry, ed. Kornberg et al., pp. 243-252; and his book with the same title: For the Love of Enzymes: The Odyssey of a Biochemist (Cambridge, Mass.: Harvard Univ. Press, 1989).

${ }^{22}$ Grunberg-Manago, "Recollections on Studies of Polynucleotide Phosphorylase" (cit. n. 20), p. 62. 
Years later, Ochoa was included in David Nachmansohn's volume German-Jewish Pioneers in Science, 1900-1933. In the part dedicated to biochemists Ochoa and his wife were described as "strong and devoted supporters of Palestine and, after the establishment of the state, of Israel. They have repeatedly visited Israel and have many good friends in the Weizmann Institute. They regularly attend the Weizmann Dinner in New York." ${ }^{23}$ The strong commitments of his Jewish colleagues who supported the new state of Israel from abroad may have inspired Ochoa's commitment to the development of biochemistry and molecular biology in Spain, the mother country to which he felt indebted even as he enjoyed the privileges of his U.S. citizenship. When the occasion arose, Ochoa would offer strong support to his Spanish colleagues and disciples.

\section{A SPANISH NOBELIST: RECEPTION OF THE AWARD IN SPAIN}

On 16 October 1959 front-page headlines in the Spanish daily newspapers announced the triumph of a Spanish scientist: "A great researcher from Spain, Doctor Ochoa, achieves the Nobel Prize in Medicine: 'I am proud as a Spaniard and because it honors Spanish medicine.' " Ochoa's actual words, quoted in the article that followed, were "I am proud as a Spaniard that the Nobel Prize honors our medical science." Another newspaper exclaimed: "The Nobel Prize award thus recognizes the exceptional scientific merits of this distinguished Spaniard who comes back to Spain anytime he can interrupt his scientific work." 24

Spanish insistence on "claiming" Ochoa is evident in the introductory remarks to one of the first and most quoted interviews that appeared after the Nobel Prize award was made public.

The Nobel Prize has just been jointly awarded to the Spanish doctor Severo Ochoa and the North American Arthur Kornberg. Medicina y cirugía auxiliar is glad to offer its readers complete information about Doctor Ochoa and his work. As Spaniards, we are proud that a fellow countryman has been awarded the highest prize a scientist can obtain. . . Those who read this interview will find, behind its technical words, a fascinating world: the magical renewal and growth of life.... Particles become tinier, with infinite combinations. What is there at the bottom, beyond the last indivisible element? Will we see it? We will likely not. It is a matter of spirit's inviolable light. ${ }^{25}$

Up to this point, apart from his regular summer vacations in the north, Ochoa had maintained contact with Spain chiefly through his relatives and his friendships with Spanish clinicians, among them Carlos Jiménez Díaz and Francisco Vega Díaz. Evidence of such relationships was eagerly sought by journalists who hoped to offer their readers information on Ochoa's research, explanations of its importance, and accounts of his contacts with the Spanish scientific community and local friends. Ochoa's cardiologist friend

\footnotetext{
${ }^{23}$ David Nachmansohn, German-Jewish Pioneers in Science, 1900-1933: Highlights in Atomic Physics, Chemistry, and Biochemistry (Berlin/Heidelberg: Springer, 1979), pp. 356-357.

${ }^{24}$ Abc, 16 Oct. 1959; and El Alcázar, 16 Oct. 1959 (these are Madrid daily newspapers) (here and elsewhere, translations into English are my own unless otherwise indicated).

${ }^{25}$ Introductory note to an interview with Ochoa published in Medicina y cirugía auxiliar, Nov. 1959, pp. 1822; the same interview appeared in the daily newspaper Pueblo on 16 Oct. 1959. The interview was first published in Indice in July 1959, pp. 3-6; the introduction to that version, signed by "F. F."-Fernández Figueroa, editor of Índice - said that Ochoa had " 'touched on' [almost touched] the Nobel Prize award." The possibility that Ochoa would receive a Nobel award was generally acknowledged, as can be deduced from an interview conducted by Juan de Neguri in Luarca, during Ochoa's vacation in the village where he was born, and published in an Asturian newspaper in June 1958; the subject is referred to as "Doctor Ochoa, presumed Nobel Prize awardee." This interview was reprinted in El Alcázar, 16 Oct. 1959.
} 
Francisco Vega Díaz, Julián Sanz Ibáñez (a disciple of Cajal), the well-known endocrinologist Gregorio Marañón, and the biochemist Ángel Santos Ruiz, among others, were called upon to explain the role of nucleic acids in heredity. The early days of Ochoa's scientific career in Madrid under Negrín, his yearly visits to his native Asturias, and his feelings as a Spaniard were emphasized.

Inevitably, in these interviews, someone would ask whether Ochoa would have won the Nobel Prize if he had stayed in Spain. The published answer was never a "no"; instead, the scientists pointed to the superior research facilities in the United States. However, when a daily newspaper from Madrid published a "yes" attributed to Ochoa's friend Vega Díaz, the supposed "source" complained to the editor:

It concerns an answer to a question never put to me: whether I think that Dr. S. Ochoa would have been able to obtain the award had he stayed in Spain. And my categorical answer is the contrary of the one that has been attributed to me. That is: No. He could not have obtained it, for reasons that are in the minds of all those who do research in Spain. ... Dr. S. Ochoa ... would have needed very different resources from those that could have been offered to him in our deep poverty and also different environmental circumstances. ${ }^{26}$

Vega Díaz mentioned this complaint in a talk on Ochoa delivered to the Asociación de Mujeres Universitarias (Association of University Women) to celebrate the Nobel award. The cardiologist quoted Ochoa's comments about his complaints in a long paragraph. He reported that Ochoa had said, "I do not agree with you that [if I had stayed] in Spain I could not have obtained [the Nobel Prize]." Yet in the margin of his own copy of the paper, sent to him by Vega Díaz, Ochoa had written "I didn't say this." Vega Díaz noted that Ochoa was appointed a Privatdozent by Meyerhof; but Ochoa remarked, "Not correct." Vega Díaz's claim that "Ochoa carried out the most significant work in worldwide biochemistry" produced another comment from Ochoa: "freshly exaggerated."27

The "invention" of remarks attributed to Ochoa by some of his Spanish friends and colleagues must be understood in the context of the Franco dictatorship, a time when freedom of the press was unknown. Anything journalists wrote or quoted had to pass censorship. But while this measure pertained to newspapers, weekly magazines, books, and periodicals, it could be evaded in the cases of specialized publications - for example, scientific journals - like the one that published Vega Díaz's talk to the university women. This particular text was much more informative than any other published at the time, including material on Ochoa's prewar years, his decision to leave Spain, and other points usually censored by the authorities. ${ }^{28}$

The journal of the Clínica de la Concepción, edited by clinic director Carlos Jiménez Díaz, paid homage to Ochoa in its March 1960 issue, a celebration volume acknowledging "his brilliant triumph." Jiménez Díaz was a mentor to the young Ochoa in his Madrid institute before the Civil War, recognizing his scientific ability, and had stayed in contact with him ever since; his reminiscences were full of respect and admiration. Though

\footnotetext{
${ }^{26}$ For the published "yes" see $Y a, 17$ Oct. 1959; for the complaint see Francisco Vega Díaz to the director of $Y a, 17$ Oct. 1959 (copy in the Severo Ochoa Papers).

${ }^{27}$ Vega Díaz's talk was published as “Severo Ochoa: Desde el mirador de la amistad y lección para el futuro (texto leido en el homenaje rendido a Severo Ochoa por las Mujeres Universitarias en el Instituto Internacional de Madrid, afecto a la Embajade de Estados Unidos)," Boletín del Instituto de Patología Médica, 1960, 15:106120. A copy is attached to Francisco Vega Díaz to Severo Ochoa, 7 June 1960, Ochoa Papers; Ochoa's marginal comments are in English. On the Asociación de Mujeres Universitarias see Maria Luisa Maillard, Asociación Española de Mujeres Universitarias (Madrid: AEMU-Instituto de la Mujer, 1990).

${ }^{28}$ Vega Díaz, "Severo Ochoa."
} 
Jiménez Díaz did not mention the fact that Ochoa was born in Spain, the final words of his introductory remarks both acknowledged the Nobelist's "feelings of love and gratitude to the noble country [the United States] in which he was able to continue and crown his work" and noted that "we have also proofs of the radical ties that link him to Spain and to his friends here, among them a number of colleagues who were 'in the same boat."' The respect and affection were mutual; in his emotional letter of acknowledgment Ochoa referred to Jiménez Díaz as both his "maestro" and his "amigo."29

Ochoa's award elicited intense feelings among researchers and clinicians in the medical and biological research community. Not since the same prize had been given to Santiago Ramón y Cajal in 1906, for his work on neurons, had a Spaniard received such scientific recognition. The 1959 Nobel Prize vindicated those who championed Spanish capability in science and opened a new chapter in a historical debate dating back to the mid-eighteenth century: Spain's relative "backwardness" in science had been lamented - and lambastedwhile defenders found few counterbalancing achievements to point to. Sanz Ibáñez certainly had this dispute in mind when he insisted that Ochoa's Nobel "shows that Spaniards can do research work when there is support for it." Santos Ruiz, a professor of physiology and biochemistry at the University of Madrid School of Medicine, made the same point when presenting Ochoa's work before the Spanish National Academy of Pharmacy in March 1960: "The problem of Spanish [scientific] output is too complex to tackle at this time. Let me just note [that] "wisdom consists in pursuing the most sublime aims with the best means"; he added that the perception of Spaniards as unable to do good scientific work was a prejudice and described Ochoa as "our second Nobel Prize awardee." 30

A combination of feelings met the reception of the award in the Spanish media. Censorship and national pride together contributed to the effort to construct Ochoa as a national hero. However, some cautious persons who were interviewed emphasized aspects of both the prize and the awardee that led to bitter claims about the lack of support for research in Spain-although Spain in 1959 was not an auspicious setting for complaints. After Joaquin Ruiz-Giménez, a professor of legal philosophy, became minister of education in 1951 there had been a period of greater political freedom for universities. Ruiz-Giménez was dismissed, however, after a Congreso de Escritores Jóvenes (Meeting of Young Writers) convened in Madrid in March 1956 without governmental permission. During the subsequent demonstrations at the University of Madrid, a student was badly hurt by a bullet from an undetermined source and some professors and students were imprisoned. The next minister of education focused on technical achievements. ${ }^{31}$ Promising periods alternated with more difficult times during the four long decades of Franco's regime.

Ochoa noted that "the reaction to the prize in Spain was one of great satisfaction, even in official circles." In response to a letter from the Swedish biochemist Hugo Theorell,

${ }^{29}$ Carlos Jiménez Díaz, "Homenaje al doctor S. Ochoa Albornoz,” Revista Clínica Española, 1960, 78(3):159160; and Ochoa to Carlos Jiménez Díaz, 1 Sept. 160, Ochoa Papers. See also Jiménez Díaz to Ochoa, 28 Jan. 1960, Ochoa Papers.

${ }^{30} Y a, 17$ Oct. 1959 (quoting Sanz Ibáñez); and Ángel Santos Ruiz, "La obra científica del profesor Ochoa, premio Nobel de Fisiología y Medicina 1959: Sesión del 10 de marzo de 1960," Anales de la Real Academia de Farmacia, 1960, 26(3):191-202. On this historical debate in Spain see Enrique García Camarero and Ernesto García Camerero, eds., La polémica de la ciencia española (Madrid: Alianza, 1970).

${ }^{31}$ On the construction of Ochoa as a Spanish hero see Arthur Kornberg, "Severo Ochoa (24 September 19051 November 1993)," Proceedings of the American Philosophical Society, 1997, 141:479-491. On the Ministers of Education and their achievements related to science see Santiago Garma and José Manuel Sánchez Ron, "La Universidad de Madrid y el Consejo Superior de Investigaciones Científicas," Alfoz, 1989, nos. 66-67, pp. 5977. For a primary source on the 1956 events see Pedro Laín Entralgo, Descargo de conciencia (Madrid: Alianza, 1989). 
head of the Medical Nobel Institute and himself a 1955 Nobelist for his work on the nature and mode of action of oxidation enzymes, Ochoa referred to a question "about the Spanish ambassador" and said, "We would be rather pleased if he were invited [apparently, to the ceremony where the prize was to be conferred]. . . We would like to think in this occasion that he would represent our country of birth rather than its accidental present government." 32

The Spanish authorities established official relations with Ochoa just after the award was announced: in January 1960 the secretary-general of the CSIC, José María Albareda, wrote Ochoa a letter announcing his appointment as an honorary counselor of that institution, a move approved by the minister of national education. The next communication came in November, when Albareda wrote concerning planning for the first Spanish meeting on biochemistry, to be held in July 1961. The publicity surrounding the Nobel Prize provided the opportunity to bring biochemistry into public view, and its practitioners hoped to channel the new awareness into increased support for the discipline as separate from physiology, which had long been the focus of biomedical training. ${ }^{33}$ Ochoa agreed to chair the meeting and suggested that Albareda contact two Spanish biochemists, Alberto Sols and Julio Rodríguez Villanueva. Both were engaged in research in Madrid after training periods abroad: Sols, who had spent two years working under the Coris at Washington University, did research on enzymology; while Rodríguez Villanueva, who had trained under the English microbiologist Ernest Gale in Cambridge at Ochoa's suggestion, worked on microbial biochemistry. After consultation and discussion as to whether the meeting should be devoted to discussions of the situation of biochemistry, it was organized as a scientific congress - as Ochoa had recommended. The discussion on biochemistry in Spain took place in a closed session on the last day of the congress-again following Ochoa's proposal. ${ }^{34}$

Ochoa served as chairman of this first Spanish meeting on biochemistry, held from 1922 July 1961 in Santander. (See Figure 1.) His talk, given in the closing session, on the metabolism of propionic acid displayed his continuing interest in biochemical subjects. At this time, however, he was also working on the biological function of PNPase-its presumed role in the synthesis of ribonucleic acid. Ochoa had offered to speak either on PNPase or on the metabolism of propionic acid; that Sols chose the latter topic reveals both his own biochemical commitments and the limited state of knowledge about RNA in the Spanish scientific community at the time. In this context, then, Ochoa stressed his earlier contributions to the biochemistry of enzymes, work much more related than his PNPase investigations to the Spanish biochemical reality reflected in the meeting program, where most contributions concerned microbial chemistry, carbohydrate metabolism, and clinical biochemistry. ${ }^{35}$

\footnotetext{
${ }^{32}$ Ochoa to Hugo Theorell, 4 Nov. 1959, Ochoa Papers (Ochoa wrote in English). See also Kornberg, "Severo Ochoa."

${ }^{33}$ José María Albareda to Ochoa, 29 Jan. 1960 (there is a handwritten note at the bottom: "Accepted with thanks [no carbon]"); and Albareda to Ochoa, 12 Nov. 1960, Ochoa Papers. See also Santesmases and Muñoz, "Scientific Organizations in Spain."

${ }^{34}$ Ochoa to Albareda, 5 Dec. 1960; Alberto Sols to Ochoa, 31 Jan. 1960; and Ochoa to Sols, 6 Jan. 1961, Ochoa Papers. On Sols see María Jesús Santesmases, Alberto Sols (Alicante: Instituto de Cultura Juan Gil-Albert, 1998). On Rodríguez Villanueva see Santesmases and Muñoz, "Scientific Periphery in Spain” (cit. n. 2). On the microbiology of Ernest Gale see Hans-Jörg Rheinberger, "Comparing Experimental Systems: Protein Synthesis in Microbes and in Animal Tissue at Cambridge (Ernest F. Gale) and at the Massachusetts General Hospital (Paul Zamecnik), 1945-1960," J. Hist. Biol., 1996, 29:387-416.

${ }^{35}$ Ochoa suggested the two possible topics in Ochoa to Sols, 25 May 1961, Alberto Sols Papers: "It could be
} 


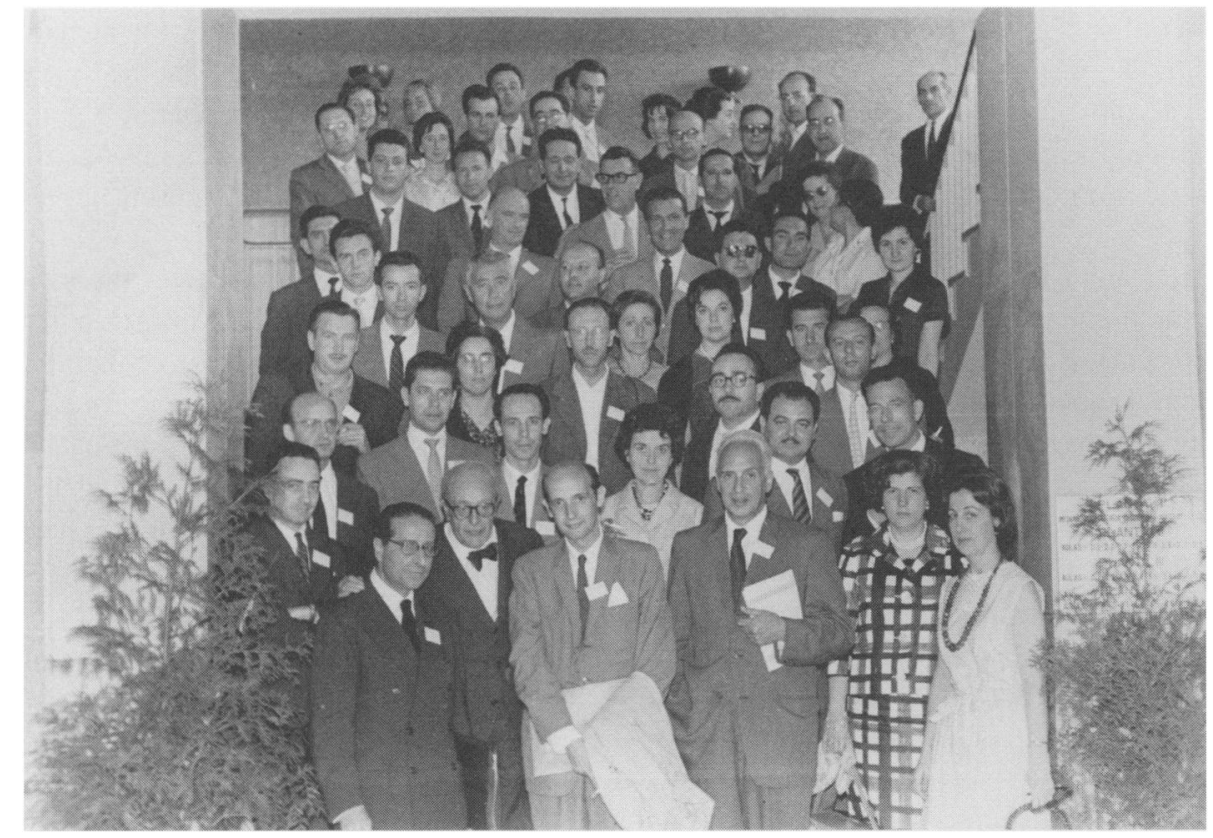

Figure 1. Ochoa and the participants in the first meeting of the Spanish biochemists, Santander, 1922 July 1961. Front row, left to right: José Luis Rodriguez-Candela, Carlos Jiménez Diaz, Santiago Grisolía. Ochoa is the third person from the right in the first row. Courtesy of the Sociedad Española de Bioquímica.

Less than a month later, in August 1961, the International Meeting on Biochemistry held in Moscow marked Ochoa's engagement in the race to decipher the genetic code. When Marshall Nirenberg and Heinrich Matthaei, from the U.S. National Institutes of Health, reported that, using poly- $U$ as a messenger, they were able to synthesize polyphenylalanine, Ochoa realized that he had the tool in his lab-PNPase-that would allow Nirenberg and Matthaei to obtain a polyribonucleotide that acted as messenger. This showed for the first time how a triplet of bases codified the synthesis of an amino acid in the test tube and confirmed the so-called central dogma of molecular biology: that genetic information goes from DNA to RNA and from RNA to proteins (composed of amino acids). Ochoa and his collaborators Joe Speyer and Peter Lengyel were working with a cell-free protein-synthesizing system first developed by Paul Zamecnik after François Jacob and Jacques Monod proposed that RNA might be a messenger in protein synthesis; following Nirenberg and Matthaei's communication, Ochoa was able to contribute to deciphering the genetic code. ${ }^{36}$ At this meeting, as well, the first president of the International

on the biosynthesis of ribonucleic acid or on the metabolism of propionic acid in animal tissue. In both cases we have recent results." Ochoa mentioned the connections between DNA and RNA synthesis that made him "speculate a little bit on the enzymatic mechanisms of transmission of genetic information." Regarding propionic acid, Ochoa told Sols about the isolation of propionil carboxylase, noting results "on carboxylation and decarboxylation of the enzyme itself that shed light on the mechanism of enzyme action." There is a program from this first Spanish meeting on biochemistry- "Reunión Bioquímica de Santander, julio, 1961"-in the Sols Papers.

${ }^{36}$ Peter Lengyel, "Ten Years in Protein Synthesis," in Reflections on Biochemistry, ed. Kornberg et al., pp. 
Union of Biochemistry, Marcel Florkin, was succeeded by Kaj Linderstom-Lang of Denmark. Ochoa's international standing was recognized when, after Linderstom-Lang's death later in 1961, he was elected the new president, a position he would hold until 1967.

Another consequence of Ochoa's increasing international prominence, his concomitant influence in Spain, and the support Spanish biochemists were receiving from science policy authorities was the creation of the Sociedad Española de Bioquímica (SEB) in 1963. Top authorities in the ministry of education and at the CSIC were beginning to promote Spanish biochemistry and to establish its presence in the field more broadly. Alberto Sols and Ángel Santos Ruiz were sent as Spain's delegates to a preparatory meeting, held in Oxford in 1963, in anticipation of the founding of the Federation of European Biochemical Societies (FEBS) ${ }^{37}$ Creation of a national society was a prerequisite for Spanish participation in the FEBS, formally established in 1964. The SEB was founded at the second meeting of Spanish biochemists, held in Santiago de Compostela in August 1963. (See Figure 2.) Chaired by Ochoa, this meeting had the explicit support of the minister of education, Manuel Lora Tamayo, who was also a professor of organic chemistry at the University of Madrid and who gave an invited talk.

This second meeting of Spanish biochemists reflected the growing importance of cell regulation as a subject; enzymes remained a popular topic as well. Regulatory issues were introduced by Sols and many of his collaborators - among them Margarita Salas, Eladio Viñuela, Gertrudis de la Fuente, and Claudio F. Heredia-and also by Manuel Rosell, a biochemist who had just come back from Earl Sutherland's laboratory at the Western Reserve University of Cleveland to do research and teaching on biochemistry at the University of Barcelona. Sols himself gave a long talk on enzymatic regulation and metabolic control that reflected the work being done by Monod, Jacob, and Jean-Pierre Changueux. ${ }^{38}$ The Argentinean biochemist Luis Leloir spoke on his work on nucleotide diphosphate in carbohydrate synthesis (which would receive the Nobel Prize in 1970), and Juan Oró, a Spanish chemist who held a professorship in Houston, discussed prebiotic chemistry.

The lone contribution on molecular biology at the second meeting of the Spanish biochemists was Ochoa's closing lecture on the genetic code; by this point in 1963, both his laboratory and that of Marshall Nirenberg at the National Institutes of Health had finished deciphering the code, an effort in which PNPase had been instrumental. At the time Peter Lengyel, Joe Speyer, Wendell Stanley, Jr. (son of the well-known virologist Wendell Stanley), Albert Wahba, and Margarita Salas were all involved in further work on reading the code; as Grunberg-Manago put it, Ochoa was "personally committed to this project and the technical resources of the department were fully utilized to provide the large number of compounds required for the decoding work." 39

309-316. On Zamecnik's cell-free protein-synthesis system see Rheinberger, Toward a History of Epistemic Things (cit. n. 1). On the deciphering of the genetic code see Judson, Eighth Day of Creation (cit. n. 1); Lily E. Kay, "Who Wrote the Book of Life? Information and the Transformation of Molecular Biology," Science in Context, 1995, 8:151-179; Kay, "A Book of Life? How the Genome Became an Information System and DNA a Language," Perspectives in Biology and Medicine, 1998, 41:504-528; and Kay, Who Wrote the Book of Life? A History of the Genetic Code (Stanford, Calif.: Stanford Univ. Press, 2000), Ch. 7. On the informational concepts applied to the "code" see also Evelyn Fox Keller, "The Body of a New Machine: Situating the Organism between Telegraphs and Computers," in Refiguring Life: Metaphors of Twentieth-Century Biology (New York: Columbia Univ. Press, 1995), pp. 79-118; and Judson, Eighth Day of Creation, Ch. 8.

${ }^{37} \mathrm{On}$ the creation of the SEB and its connection to the creation of the FEBS see Santesmases and Muñoz, "Scientific Organizations in Spain."

${ }^{38}$ On Sols's scientific trajectory and the active transformation of regulatory issues in his laboratory see Santesmases, "From Intestine Transport to Enzymatic Regulation" (cit. n. 5).

${ }^{39}$ Grunberg-Manago, "Severo Ochoa" (cit. n. 12), p. 361. A conference program is preserved in the Sols Papers: "II Reunión de bioquímicos españoles: Universidad de Santiago de Compostela, 1-3 agosto 1963." 


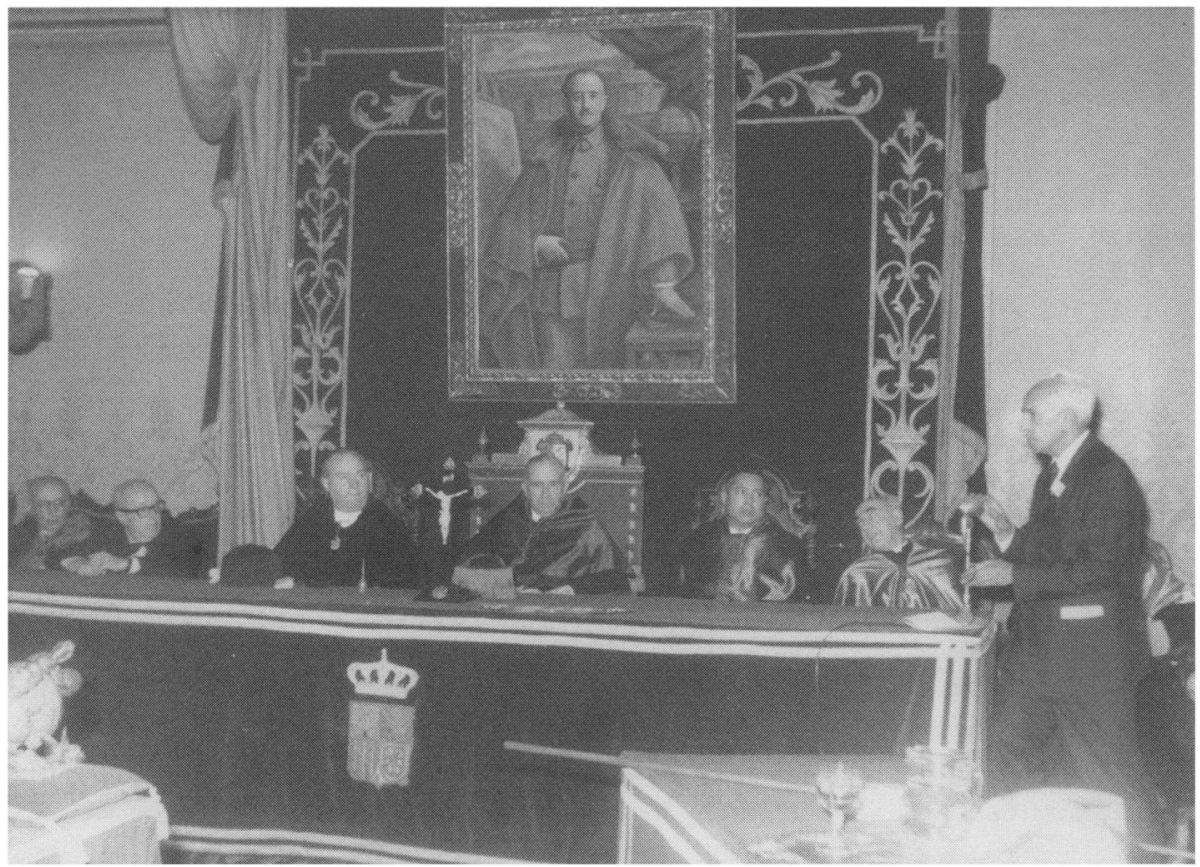

Figure 2. Ochoa addressing the second meeting of Spanish biochemists, Santiago de Compostela, 3 August 1963. The chairman is Manuel Lora Tamayo, minister of education and professor of organic chemistry at the University of Madrid. Carlos Jiménez Díaz is second from the left; José María Albareda, a priest and secretary-general of the CSIC, is second from the right. Courtesy of the Sociedad Española de Bioquímica.

\section{VITH MEETING OF THE FEDERATION OF EUROPEAN BIOCHEMICAL SOCIETIES, 1969}

Since the end of World War II, Spain had been opening its trade markets through the reestablishment of diplomatic relationships with the Allies. Although Spain did not benefit from the Marshall Plan, which was helping much of the rest of Europe recover from the war, a bilateral agreement that, among other things, provided for the creation of the Spanish-American Joint Committee, was signed in 1953. This U.S. support was important to research activities in Spain. During the 1960s the Spanish economy expanded to the level achieved by its geographical neighbors and political allies..$^{40}$ New government plans for economic development were implemented and industrial production began to rise.

In 1963 the Organization of Economic Cooperation and Development (OECD) was created in Paris, an outgrowth of the earlier European Organization of Economic Cooperation (OEEC), formed in 1948: the members were those of the OEEC (including Spain, which had joined in 1959) plus the United States and Canada. One of its sectors of influence was science policy. Under the influence of the OECD, new objectives for the promotion of technical and scientific training and research were established in Spain. Progress was

${ }^{40}$ Spain had numerous bilateral agreements with the Allied countries. See Guirao, Spain and the Reconstruction of Western Europe (cit. n. 6). For a review of Spain's economic recovery and expansion see Pablo Martín Aceña, "La difícil convergencia de la economía española," Papeles de Economía Española, 1995, no. 63, pp. 78-92. 
not always smooth, however; the Franco dictatorship both exerted and responded to complex influences.

In 1968, mainly because of grave political problems at the universities, including strikes and demonstrations that canceled almost all teaching in the academic year 1967/68 and led to the permanent presence of police in university buildings, Manuel Lora Tamayo, who had been appointed in 1962, resigned as minister of education. His replacement was José Luis Villar Palasí, the brother of two well-known Spanish biochemists, Vicente Villar (the chairman of biochemistry at the University of Barcelona School of Pharmacy) and Carlos Villar (a disciple of Sols who had moved to the United States and worked under Earl Sutherland). One of Villar Pilasí's first decisions was to create three new universities - in Madrid, Barcelona, and Bilbao-to address the so-called problema de la universidad. ${ }^{41}$ Spanish university students and professors were raising the same sorts of social criticisms that would lead to the notorious events in Paris in May 1968. The new minister of education perceived - or at least encouraged the perception-that the problema de la universidad in Spain was due to overcrowded universities. In reality, the universities faced a crisis, shaped by increasing demands for freedom and justice that the dictatorship could not countenance, that affected other professional sectors as well. The total number of university students at this time was around two hundred thousand, not out of line with numbers in neighboring countries. Nonetheless, Villar Palasí used overcrowding as the rationale both for the creation of new universities in the most populous Spanish cities and for the reform of existing universities. The ministry team, composed of Spanish officials from UNESCO, soon suggested a complete reform of the educational system, from primary school through the universities. ${ }^{42}$ As part of the program of university reforms, many Spanish scientists who worked abroad were asked to offer suggestions. They were expected to contribute ideas on the new system as a whole and also to make specific program recommendations with reference to their particular fields (it was hoped that responsiveness to the suggestions might eventually work to entice these scientists to return to Spain). Among the first to be contacted were the neuroscientist José Manuel Rodríguez Delgado, the physicist Nicolás Cabrera, and Ochoa. In 1968 Ochoa was visited by Ricardo DíezHochleitner, the undersecretary of the ministry of education and a UNESCO official on leave; he was persuaded to accept the chairmanship of the committee that was to discuss

\footnotetext{
${ }^{41}$ Lora Tamayo's own records are in Manuel Lora Tamayo, Lo que yo he conocido: Recuerdos de un viejo catedrático que fue ministro (Puerto Real, Cádiz: Federico Joly-Ingrasa, 1993). On the Spanish universities at the end of the 1960s see Antonio Fontán, Los católicos en la universidad española actual (Madrid: Rialp, 1961); Carlos París, La universidad española actual: Posibilidades y frustraciones (Madrid: Cuadernos para el Diálogo, 1974); and Ricardo Montoro, La universidad en la España de Franco (Madrid: Centro de Investigaciones Sociológicas, 1981). On the University of Madrid see Garma and Sánchez Ron, "Universidad de Madrid" (cit. n. 31).

${ }^{42}$ Boletín Oficial del Estado, 7 June 1968, decree of 6 June: "Universidades: Medidas urgentes de reestructuración: Crea facultades e institutos politécnicos"; and "Reforma de la Universidad: Conferencia de prensa del Ministro de Educación Ciencia Prof. Villar Palasí,” Enseñanza Media, 1968, no. 191, pp. 961-969. In this press conference the minister mentioned the need for a "democratization of [university] education that may, however, produce a personal and active learning as a result of the reduction of the dimensions of the [current] teaching units." Such reductions were apparently an expected consequence of the creation of new universities that would eventually reduce the number of students in the existing ones. See also "Inauguracíon del curso universitario: 'La universidad, piedra clave en el proceso educativo nacional: Debemos procurar el acceso a ella de todos los jóvenes españoles con capacidad decisión,' dice el ministro Dr. Villar Palasí,” ibid., 1968, nos. 195-196, pp. 1067-1074; this quotes the minister on the inauguration of the academic year 1968/69 at the University of Madrid, Paraninfo de San Bernardo, 14 Oct. 1968. For primary sources on the new minister of education and science see Inés Chamorro, "Informes y bibliografía sobre la Ley General de Educación," in La Ley General de Educación veinte años después, Revista de Educación, 1992, pp. 433-438; see the other contributions to this special issue as well.
} 
the reform proposals for the university system. But Ochoa made a specific request as well: he recommended the founding of a new institute for molecular biology in Madrid and suggested that Sols be contacted for further suggestions. Apparently Ochoa was familiar with the proposal, first circulated among Spanish biologists in 1966, for a new postgraduate school of fundamental (basic) biology and hoped to tie that project to the new reforms. ${ }^{43}$

By this point, the European Molecular Biology Organization (EMBO) had been created in Geneva in 1964, and UNESCO had published its own document on the need for international cooperation in the biological sciences, a report to which Ochoa-as the U.S. representative - had contributed, along with many distinguished European biologists such as Max Perutz (EMBO representative), Hugo Theorell (Swedish representative), and Adriano Buzzati-Traverso (Italian representative). Spanish biochemists were eager to participate in the expansion of the biological sciences in Europe; this might be considered the background for the first proposal of a Spanish postgraduate school for biological research. Ochoa had explicitly offered his help with the next draft of the proposal for what was to be called a molecular biology institute, dated June 1968. This draft included a request for support from the Spanish-American Joint Committee in the form of training fellowships and grants-in-aid. ${ }^{44}$

Ochoa's October 1968 trip to Spain, tightly scheduled with meetings and interviews, included a visit to the minister of education at which Ochoa presented the proposal for a molecular biology institute. He was invited to join the teaching staff of the newly created Universidad Autónoma de Madrid but declined: "I have to confess that I cannot abandon my teaching and research program at New York University." He did, however, express a wish to help in recruiting scientists that "had to leave Spain in earlier times." The SpanishAmerican Joint Committee approved a grant to support the elaboration of two projects: one for Madrid and another for Barcelona. Ochoa and Juan Oró worked together to take advantage of a new science policy that eventually would support more than one Spanish center for biological research. The negotiations also involved Santiago Grisolía, Ochoa's former research fellow and a professor at the University of Kansas, Alberto Sols, and his collaborator Carlos Asensio. ${ }^{45}$

Meanwhile, Ochoa's scientific work continued. During the decade from 1959 to 1969 PNPase proved not to have the role attributed to it in the in vivo synthesis of biologically active RNA. Kornberg's enzyme, which had been envisaged as a DNA polymerase, proved similarly disappointing. ${ }^{46}$ Ochoa and his coworkers would later report on an RNA poly-

\footnotetext{
${ }^{43}$ Ricardo Díez-Hochleitner, "La reforma educativa de la LGE de 1970: Datos para una crónica," in La Ley General de Educación veinte años después, Rev. Edu., 1992, pp. 261-278. On the proposal see "Anteproyecto de una escuela graduada de biología fundamental en el Centro de Investigaciones Biológicas: Presentado por los Institutos Gregorio Marañón y de Biología celular," Madrid, Jan. 1966, Sols Papers. On these documents see Santesmases, Alberto Sols (cit. n. 34).

${ }^{44}$ On EMBO see Abir-Am, "From Multidisciplinary Collaboration to Transnational Objectivity" (cit. n. 1); and Santesmases and Muñoz, "Scientific Organizations in Spain." The UNESCO report was UNESCO/AVS/LS/ 445/3 rev. (17 Jan. 1966): "Etude de besoins actuels de cooperation internationale dans le domain des sciences biologiques fondamentales," Papers of the Spanish delegation at the European Conference of Molecular Biology. For the draft proposal see "Posibilidades de cooperación hispano-norteamericana para la promoción postgraduada en biología molecular," Madrid, June 1968, Sols Papers. On the Joint Committee see Asociación Cultural Hispano-Norteamericana, Influencia norteamericana en el desarrollo científico español: Coloquios de El Escorial (Madrid: ACHNA, 1982).

${ }^{45} \mathrm{Abc}, 20$ Oct. 1968, p. 8; and "Comité Binacional Hispano-Norteamericano: Promoción postgraduada; Informe sobre las gestiones realizadas en la visita a España de los prof. S. Ochoa, J. Oró y S. Grisolía,” Madrid, Nov. 1968 [report prepared by Carlos Asensio], Sols Papers.

${ }^{46}$ Ochoa suggested the in vivo role of PNPase in 1957, together with Leon Heppel: Severo Ochoa and Leon A. Heppel, "Polynucleotide Synthesis," in The Chemical Basis of Heredity, ed. William D. McElroy and Bentley
} 
merase, distinct from PNPase, that catalyzed the incorporation of nucleotides from ribonucleoside triphosphate into RNA. And Kornberg's son Tom reported a DNA polymerase activity in the early 1970s. Despite its lack of biological significance, PNPase provided Ochoa and his collaborators with a tool that led to deciphering the genetic code after the first achievement made public by Marshall Nirenberg at the Moscow conference in 1961.47

After the initial elucidation of triplets (or codons), Ochoa's postdoctoral fellows Salas, Wahba, and Stanley embarked on investigations of the directionality and termination of DNA transcription. Further research in Ochoa's group concerned the translation of the genetic message from messenger RNA into proteins. Ochoa was also interested in the synthesis of viral RNA, a topic his postdoctoral student Charles Weissmann started studying in the early 1970s. ${ }^{48}$ By the time of the sixth meeting of the Federation of European Biochemical Sciences, in 1969, Ochoa was fully committed to molecular aspects of research, especially regarding the synthesis of nucleic acids and proteins. Questions about synthesis were at the same time deeply biochemical, as they had been for twenty years.

Such work had a direct influence on research in Spain. Early practitioners in this vein were Margarita Salas and Eladio Viñela, both of whom were established in Madrid in 1967 after postdoctoral training periods in Ochoa's laboratory. David Vázquez had returned from Ernest Gale's laboratory in Cambridge to conduct research on the action of antibiotics in protein synthesis. Jaume Palau, trained in London, and Juan Antonio Subirana, who did postdoctoral work under Paul Doty in New York and at the Weizmann Institute in Rehovot, Israel, were both concerned with the structure of nucleic acids. Ángel Martín Municio, chair of biochemistry and molecular biology at the Universidad Complutense, in Madrid, and now president of the Spanish Royal Academy of Science, organized the first postgraduate courses on molecular biology in the late 1960s. ${ }^{49}$ All these scientists were instrumental in introducing molecular biology in Spain.

Members of the Sociedad Española de Bioquímica made plans for the sixth meeting of the FEBS, to be held in Madrid in April 1969. Julio Rodríguez Villanueva, Alberto Sols, Federico Mayor (a biochemist who would later be appointed director-general of UNESCO

Glass (Baltimore: Johns Hopkins Press, 1957), pp. 615-638. On the activity of the enzyme see also Charles Weissmann, “A Phage in New York," in Reflections on Biochemistry, ed. Kornberg et al., pp. 283-292, esp. pp. 283-284. In current textbooks of biochemistry and molecular biology the role of PNPase as a tool in deciphering the genetic code is acknowledged and its catalytic action is described as shifted to the degradation more than the synthesis of RNA. See Lubert Stryer, Biochemistry, 4th ed. (New York: Freeman, 1995), Ch. 5. Kornberg discusses the story of DNA polymerase in Kornberg, For the Love of Enzymes (cit. n. 21), pp. 217-220, in a section entitled "DNA Polymerase under Indictment." I am grateful to Angela Creager for having emphasized the complexity of early developments in research on polymerization enzymes.

${ }^{47}$ Debi P. Burma, Hans Kröger, Severo Ochoa, Robert C. Warner, and Jacques D. Weill, "Further Studies on Deoxyribonucleic Acid-Dependent Enzymatic Synthesis of Ribonucleic Acid," Proceedings of the National Academy of Sciences, 1961, 47:749-752; Joseph Krakow and Ochoa, "RNA Polymerase from Azobacter vinelandii," Methods in Enzymology, 1963, 6:11-17 (this article was followed by others by the same authors later in 1963); and Kornberg, For the Love of Enzymes, pp. 217-220. For a retrospective discussion of developments in Ochoa's lab during the "genetic code" years see the testimony of his research fellow Carlos Basilio, quoted in Grande and Asensio, "Ochoa and the Development of Biochemistry" (cit. n. 10), p. 9. See also GrunbergManago, "Severo Ochoa" (cit. n. 12); and Grunberg-Manago, "Recollections on Studies of Polynucleotide Phosphorylase" (cit. n. 20).

${ }^{48}$ Grunberg-Manago, "Severo Ochoa,” pp. 362-363.

${ }^{49}$ María Jesús Santesmases, "Tradición y modernización: Aspectos cognitivos y sociales en los inicios de la biología molecular en España," Arbor, 1997, no. 614, pp. 79-109. Eladio Viñuela died in March 1999. In obituaries and commemorative sessions his disciples and colleagues stressed his research contributions and his key role in strengthening Spanish molecular biology. See Jesús Avila and Federico Mayor, Jr., "Eladio Viñuela," Nature, 1999, 400:822; and the commemorative volume Fago 29 y los orígenes de la biología molecular en España, ed. Avila, Manuel Perucho, and Carlos López Otín (Madrid, 1999). The first Eladio Viñuela Memorial Lecture was given by Manuel Perucho at the Universidad Autónoma de Madrid on 15 Feb. 2000. 
after serving as Spanish minister of education and science), David Vázquez, Gertrudis de la Fuente (a close collaborator of Sols), and Ángel Santos Ruiz (professor of physiology and biochemistry at the University of Madrid School of Pharmacy) were all on the organizational committee. At the end of January, however, a nationwide state of emergency that would last for three months was declared following student demonstrations that closed the universities of Madrid and Barcelona. There was disagreement concerning this measure in the Cabinet; some ministers and top officials regarded it as too harsh. Up to two hundred students and professors were expelled from the universities, and a student, Enrique Ruano, died in police custody in Madrid. Although the authorities claimed he committed suicide by jumping from a third-floor window, suspicions about the death helped to intensify forbidden demonstrations and the occupation of churches in expression of solidarity with the imprisoned. The crisis was particularly unfortunate for the monarchic elite, who were working hard to ensure that the young prince Juan Carlos de Borbón would succeed Franco on his death; it was not possible to announce the planned succession while the country was under a state of emergency. ${ }^{50}$

The state of emergency also affected plans for the forthcoming FEBS meeting. In February faculty members of the University of Konstanz strongly suggested that the meeting be canceled "in view of the latest dictatorial acts in Spain." Some member biochemical societies discussed the Spanish political situation and even voted as to whether they would take part in the meetings: French, Dutch, and Swedish scientists were most active in expressing discomfort. The secretary-general of the FEBS, H. V. R. Arnstein, and the treasurer, Prakash Datta, visited Madrid in February to evaluate the situation for themselves; on returning to London, they recommended that, "unless the Spanish political situation suddenly and seriously deteriorates, the meeting should go on as planned." Apparently things were calmer at the experimental science centers than at the universities. The former were described as "untroubled," and, although teaching had come to a halt, research work and training continued. Spanish authorities guaranteed the biochemists access to the meeting. Even before the state of emergency was suspended at the end of March, the representatives issued a report of their visit stressing that the FEBS was a nonpolitical organization and offering criteria for "the practicability of a scientific meeting in a delicate situation" - primarily participants' freedom of speech and movement. ${ }^{51}$ Assurances aside, some speakers and session chairs refused to take part in the Madrid meeting, and in the last month and a half Sols was forced to make numerous international telephone calls to find substitutes. In the end, the meeting was held as planned from 7 to 11 April. Some 2,200 scientists attended, among them seven Nobel Prize winners; Ochoa was an honorary president and organizer. He was joined by the Spanish molecular biologists David Vázquez and Eladio Viñuela for three sessions on "The Biosynthesis of Macromolecules." 52

\footnotetext{
${ }^{50}$ For a primary source on the disagreement among Franco's ministers see the memoirs of one of those ministers: Laureano López Rodó, La larga marcha hacia la monarquía (Barcelona: Noguer, 1977), pp. 303312; on the problems the crisis posed for the monarchists see esp. p. 310. A historical account can be found in José Antonio Biescas and Manuel Tuñon de Lara, España bajo la dictadura franquista (1939-1975) (Barcelona: Labor, 1980), Ch. 6.

51 "FEBS in Spain," Nature, 1969, 221:702-703 ("latest dictatorial acts"); "Minutes of the Ninth Meeting of the Council held in the Escuela Técnicas Superior de Ingenieros de Caminos at the Ciudad Universitaria, Madrid, Spain," FEBS Circular 88, in Sols Papers (FEBS officials' evaluation of the Spanish situation); and "FEBS Undaunted," Nature, 1969, 221:794-795 ("delicate situation").

${ }^{52}$ On Sols's last-minute efforts to find substitutes see Alberto Sols, "Influencia norteamericana en las ciencias biomédicas," in Asociación Cultural Hispano-Norteamericana, Influencia norteamericana (cit. n. 44), pp. 47-
} 


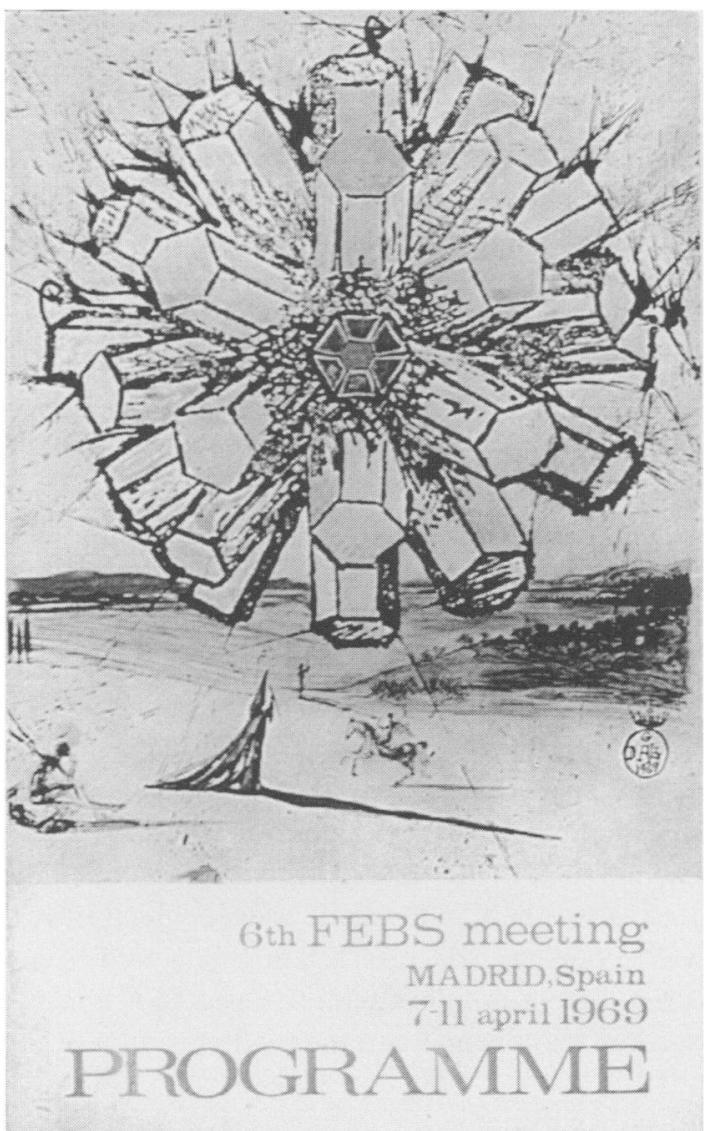

Figure 3. Program cover for the sixth FEBS meeting (in color in the original), designed by Salvador Dalí. Courtesy of the Sociedad Española de Bioquímica.

Ochoa was both an actor in and a subject of the FEBS meeting, at a time when the Spanish scientific community considered the nation to be lacking in both resources for biomedical research and positions for scientists recently trained in the relevant disciplines. ${ }^{53}$ The meeting did, however, give the disciplines considerable publicity and had the additional benefit of bringing almost all the country's biochemists, junior and senior, together in a gathering of international scientific significance. The Spanish surrealist painter Salvador Dalí provided the illustration for the meeting program cover. (See Figure 3.)

As part of the program, the FEBS Council met to discuss the crisis in Spain; the council resolved that the FEBS should stay away from politics and stipulated that the federation's

56; and Carlos Asensio, "Alberto Sols: Semblanza biográfica," Arbor, 1975, nos. 357-358, pp. 58-65. On the meeting program and events see Asensio, "VI Congreso de la Federación Europea de Sociedades de Bioquímica," ibid., 1969, no. 280, pp. 99-110. A detailed report on some of the sessions in Philip Rubery, "Protein Biosynthesis in Madrid," New Scientist, 24 Apr. 1969, pp. 174-176. Other symposium titles were "Metabolic Regulation," "Mechanisms of Enzyme Action," and "Membranes: Structure and Function." Further communications were presented in five colloquia: "Enzyme Pathology," "Biochemical Evolution," "Molecular Biology of Differentiation," "Molecular Bases of Antibiotic Action," and "Molecular Neurobiology."

${ }^{53}$ Carlos Asensio, interview, Agencia Logos, 1969, Papers of the Sociedad Española de Bioquímica. 
constituent members were not nations but scientific societies. On 10 April a round-table discussion on the teaching of biochemistry in Spain took place. The meeting, which included a select group of influential scientists - rectors of the chief Spanish universities and some émigré scientists - was held at the suggestion of José Botella, a gynecologist and rector of the University of Madrid, who recommended that they convene in a closeddoor setting "to study how to emphasize the instrumental role of biochemistry teaching." This proposal was formulated in the context of attempts to persuade Ochoa to return to Spain, even though there was not yet an agreement as to which of the university campuses in Madrid would house the new institute for molecular biology. The biochemists accepted Botella's suggestion and organized to get wider support for biochemistry in Spain. The round table was chaired by Villar Palasí himself, and all the invited scientists took part in it. Emphasizing the role of biochemistry in medical training was not only one of the most effective strategies Spanish biochemists used to win additional academic space; it also became part of the discourse on the modernization of research training. As Botella observed, it was necessary to reorient medical training so that it included biochemistry as part of the required biological knowledge. ${ }^{54}$

This combination of agendas at one of the first large and internationally important meetings of Spanish biochemists indicates that scientists and authorities alike were aware that Ochoa's presence in Spain at that time, taking a distinguished part at the meeting while negotiating with the authorities regarding a new research center for molecular biology, offered legitimation to both the research and the academic influence of biochemical practitioners. The meeting was held in the same year in which it was announced that Juan Carlos de Borbón was appointed prince of Spain and would become king on Franco's death; it seemed a period full of promise, with prospects for improvements ranging from increased political freedom and openness to the modernization of the universities. ${ }^{55}$

\section{EVENTS FROM 1970 TO 1975}

A new "Agreement of Friendship and Cooperation between the United States of America and Spain" was signed in August 1970. In its third chapter, which covered bilateral scientific and technical cooperation, medical and biological sciences were explicitly mentioned, along with atomic energy (also part of the 1953 agreement), the exploration of space, marine sciences, industrial technology, electronics, and social sciences. In September, as a result of negotiations with the Spanish ministry of education and science, Ochoa's impending return to Spain on a part-time basis was announced. "The return of Severo Ochoa to a Spanish University is certain. He will pursue scientific work and research in the Universidad Autónoma de Madrid. The sole issue that remains to be decided is the size of his laboratory," reported the Madrid daily Abc. A forthcoming appointment of

\footnotetext{
${ }^{54}$ For the Council resolution see "Minutes of the Ninth Meeting" (cit. n. 51); for Botella's suggestion see José Botella to Carlos Asensio, 23 July 1968, Sols Papers. On the round-table discussion see "Presidida por Villar Palasí: Mesa redonda sobre la enseñanza de la bioquímica," El Alcázar, 11 Apr. 1969, p. 4; and "La enseñanza bioquímica es deficitaria," Pueblo, 11 Apr. 1969, p. 20. However, some members of the Madrid science faculty complained that they had not been invited to join the discussion and insisted that biochemistry was indeed taught to their students.

${ }^{55}$ The announcement regarding Juan Carlos was made in July 1969. See Paul Preston, Franco: A Biography (London: HarperCollins, 1993), Ch. 27. For a primary source on the episode of the succession see López Rodó, Larga marcha hacia la monarquía (cit. n. 50).
} 
Ochoa as director of a new institute of molecular biology at the Universidad Autónoma was also announced. According to newspaper reports, Ochoa himself said that as soon as the institute was created he would accept its directorship; he anticipated that it would take at least two years to develop the project and added that he intended to retain his post at New York University on a part-time basis. ${ }^{56}$

Meanwhile, a new center for basic biology was created in Barcelona, led by Juan Oró and the Catalonian molecular biologist Jaume Palau. From the time of the round-table discussion held at the Madrid FEBS meeting in 1969, it was established that the Madrid research center for molecular biology would be a more ambitious and more expensive project than that to be created in Barcelona; plans for the Madrid center were being developed by a team led by Ochoa's former fellow Eladio Viñuela and the technician Javier Corral. Creation of an Institute of Molecular Biology in Madrid was officially approved in February 1971. In May, Ochoa was appointed president of its board. During 1972 the members of the board met regularly to design facilities for the new institute and to discuss its budget, which increased every time they got together. ${ }^{57}$ Plans for the building were designed by a Spanish architect, Cayetano de Cabanyes, and a U.S. consultant was asked to address the technical requirements. This was an ambitious project without precedent in Spain; at its inception, it enjoyed national political support and international backing that included a grant from the U.S. National Science Foundation, money awarded in the framework of the agreement signed in 1970.

In May 1973, however, Julio Rodríguez, the rector of the Universidad Autónoma de Madrid, published an article that included claims in support of those scientists who had stayed in Spain and praised the work they had accomplished. ${ }^{58}$ Reading between the lines, it was possible to discern some criticism of the new policy of enticing émigré scientists to return. The team planning the new molecular biology institute recognized that the return of Spanish scientists who had established careers abroad - among them Ochoa-was in jeopardy. Fearing that Villar Palasí, the minister of education who supported the institute, would soon be dismissed, the team worked hard to present a definitive project. In June 1973 the former vice-president of the government, Admiral Luis Carrero Blanco, was appointed president; among his Cabinet changes was the appointment of a new minister of education: Julio Rodríguez. Plans for the molecular biology institute came to a halt.

On the morning of 20 December 1973 Carrero Blanco was assassinated when a bomb exploded in his official car. A new Cabinet was appointed in January 1974, with Cruz Martínez Esteruelas as minister of education. His undersecretary, Federico Mayor-professor of biochemistry at the Autonomous University and a former rector of the University

${ }^{56}$ Abc, 20 Sept. 1970, 23 Sept. 1970; and Pueblo, 23 Sept. 1970. For the agreement see "Department of State for the Press: Agreement of Friendship and Cooperation between the United States of America and Spain, August 6, 1970," in Ochoa Papers. For press coverage of the news see Abc, 9 Aug. 1970. This agreement was based on the secret agreement signed in 1953; the 1970 agreement was the first on which the government offered public information. For the history of agreements between the United States and Spain during Francoism see Ángel Viñas, Los pactos secretos de Franco con Estados Unidos: Bases, ayuda económica, recortes de soberanía (Barcelona: Grijalbo, 1981).

${ }^{57}$ On the creation of the Barcelona center see Boletín Oficial del Estado, 11 Mar. 1970: "Orden de 24 de febrero por la que se crea el Instituto de Biología Fundamental en la Universidad Autónoma de Barcelona." On the creation of the Madrid institute see Boletín Oficial del Estado, 1 Mar. 1979: "Decreto 319/1971, de 8 de febrero, por el que se crea el Instituto de Biología Molecular de la nueva Universidad Autónoma de Madrid," approved by the Cabinet on 5 Feb. 1971. Ochoa's appointment as board president is announced in Ministro de Educación y Ciencia to Ochoa, Madrid, 21 May 1970, Ochoa Papers. Minutes of board meetings during 1972 can be found in the Ochoa Papers; these detail discussions about design and budgets.

58 Julio Rodríguez, "Cerebros no recuperados," Abc, 8 May 1973. 
of Granada-took the lead in resurrecting the institute project; he worked on it with Viñuela and Corral until September 1975. ${ }^{.9}$ By the time planning resumed, however, Ochoa was no longer available to direct the new research center. He had retired from New York University and accepted an offer to join the Roche Institute of Molecular Biology in New Jersey. A new building was no longer part of the plan; instead, the institute would be housed within the Science Faculty of the Autonomous University of Madrid. The budget and the scientific staff were also cut back considerably.

\section{INTERNATIONAL HOMAGE TO OCHOA, 1975}

Though the projected institute for Ochoa had not gone according to plan — and he did not feel engaged with the new version of the project-he retained his links to Spanish scientists. Looking forward to his seventieth birthday, to take place in 1975, a group of biochemists and molecular biologists put together a conference with the dual purpose of paying tribute to Ochoa and reviving his support for the new center for molecular biology in Madrid. Juan Oró and Arthur Kornberg planned the symposium, the contributions to which were eventually published in a Festschrift. ${ }^{60}$ Jaume Palau was in charge of local arrangements for the part of the conference held in Barcelona, while Carlos Asensio, by that time a research fellow at the CSIC, performed the same job in Madrid. The International Symposium on Enzymatic Mechanisms in Biosynthesis and Cell Function was held from 23 to 27 October 1975: three sessions in Barcelona on 23 and 24 October, three more in Madrid on 26 and 27 October. ${ }^{61}$

The honorary committee behind the symposium included a number of political authorities: the minister of education and science, the minister of foreign affairs, the minister of information and tourism, top authorities in the Department of Education and the Department of Health, the mayors and military officials of Madrid and Barcelona, and the U.S. ambassador to Spain, stationed in Madrid. Academic notables also played a role, among them the presidents of the Academy of Sciences and the Academy of Medicine and the rectors of the universities in Madrid and Barcelona. The scientific committee was cochaired by Kornberg and Mayor; one of its members was Duncan Clement, cultural attaché to the U.S. embassy and one of the chief supporters of the institute of molecular biology in Madrid. The organizing committee, chaired by Oró, included the biochemists Sols and Bernard Horecker, the molecular biologists Viñuela, Vázquez, and Palau, and the biological scientist Emilio Herrera; Duncan Clement also joined the Spanish scientists responsible for local arrangements. Thus political, economic, and scientific luminaries cooperated to honor one of the most celebrated Spanish-born scientists. Once again, as at the FEBS meeting held in 1969, Salvador Dalí designed the conference poster and program

\footnotetext{
${ }^{59}$ Margarita Salas, "La creación del Centro de Biología Molecular Severo Ochoa," Arbor, 1994, no. 543, pp. $81-86$.

${ }^{60}$ Information on Ochoa's continuing links with Spanish scientists comes from an interview with Juan Oró, Madrid, 23 Dec. 1996. The Festschrift volume was Kornberg et al., Reflections on Biochemistry. Kornberg and Oró planned the event during 1974, when Oró was working at the Ames Research Center in California and Kornberg was at Stanford. Both Ochoa and Kornberg suggested potential contributors; see interview with Oró, 23 Dec. 1996.

${ }^{61}$ Homenaje al Profesor Severo Ochoa en su 70 aniversario: International Symposium on Enzymatic Mechanisms in Biosynthesis and Cell Function [preliminary program, with abstracts] (Barcelona/Madrid, 23-27 Sept. 1975), Papers of the Centro de Biología Molecular. The program was edited by Oró and Cornudella and included the Spanish version of the Ochoa biography of Grande and Asensio that would be published in the Festschrift. I am also indebted to Margarita Salas, Charo Martín, Jaume Palau, and Luis Cornudella for information on these matters.
} 
cover as a gift to Ochoa. In addition, Dalí and his wife, Gala, hosted the invited speakers at a reception at the Museo Dalí in Figueras (in Gerona, North Catalonia), where most of the attendees had their posters autographed by the surrealist. The Colegio de Medicinathe professional college of physicians - also celebrated Ochoa in a special meeting held on the evening of 26 September. ${ }^{62}$

The closing event of the congress was the inauguration of the Centro de Biología Molecular at the Autonomous University of Madrid. The new research center had not yet been completely built; it was housed for the time being in the Department of Biochemistry of the Faculty of Science at that university. Although Ochoa refused until the last moment to be officially involved in the new project, he finally agreed to participate in the ceremony, having been persuaded at a meeting in Barcelona with Oró and the president of the CSIC, Eduardo Primo Yúfera. The commemorative stone was already engraved with the name of the new center-Centro de Biología Molecular "Severo Ochoa" - and the date of its proposed inauguration, 27 September 1975. However, because the execution of five members of ETA and FRAP, two political organizations that supported armed action against the Franco dictatorship, was scheduled for the same day, the organizers abruptly decided to move the inauguration up a day so that the ceremony would not be marred by student demonstrations against the executions. Thus the Centro de Biología Molecular was officially inaugurated on 26 September, one day before the date on the commemorative stone. At this session Ochoa received the first three volumes of his complete works, Trabajos reunidos de Severo Ochoa, 1928-1975, edited by Alberto Sols and Clotilde Estévez and published by the ministry of education. The hardcover copies were presented by Juan Carlos de Borbón, the prince who would become king of Spain in November 1975, when Franco died after a long illness. ${ }^{63}$ (See Figure 4.)

The symposium program included six sessions. "Energy Metabolism" was chaired by Hans Krebs and Francisco Grande; "Lipids and Saccharides" by Carl Cori and Julio Rodríguez Villanueva; "Regulation" by Ernst Chain and Santiago Grisolla; "Nucleic Acids and the Genetic Code" by Hugo Theorell and Eladio Viñuela; "Protein Synthesis" by Paul Zamecnik and David Vázquez; and "Cell Biology and Neurobiology" by David Nachmansohn and Ángel Martín Municio. These were all areas to which Ochoa himself orin the case of neurobiology - the invited speakers had contributed.

Forty-five scientists contributed to the Festschrift, which was edited by Kornberg, Oró, Luis Cornudella (a Catalonian biochemist and collaborator of Palau and Subirana), and B. L. Horecker, at the time a member of the Roche Institute of Molecular Biology and a former professor at the NYU School of Medicine. Among them were ten Nobel Prize winners-Chain, Konrad Bloch, Cori, Krebs, Fritz Lipmann, Theorell, Kornberg, Feodor Lynen, H. Gobind Khorana, and Luis Leloir-and one Nobelist-to-be, Paul Berg (1980). The achievements of this group certainly illustrated the relevance of biochemistry, with its focus on enzymes and intermediary metabolism, to research work on the genetic code, protein synthesis, and the molecular biology of viruses. These areas of research were

\section{${ }^{62}$ Homenaje al Profesor Severo Ochoa en su 70 aniversario.}

${ }^{63}$ On Ochoa's eventual acquiescence see interview with Oró, 23 Dec. 1996; regarding the planned executions see López Rodó, Larga marcha hacia la monarquía (cit. n. 50), p. 483. On the program of the closing session see "Protocolo para el acto de inauguración del Centro de Biología Molecular CSIC y Clausura del Simposium Internacional en homenaje al profesor Severo Ochoa, 27 de septiembre de 1975," Papers of the Centro de Biología Molecular. For a complete list of the ceremonies and congresses held in Spain in September 1975 in honor of Ochoa see the introduction by the editors of Trabajos reunidos de Severo Ochoa, Vol. 4, ed. Alberto Sols and Santiago Grisolía (Madrid: Fundación Colegio Libre de Eméritos, 1987), pp. ix-xii. The role played by Alberto Sols in the whole process is emphasized in Santesmases, Alberto Sols (cit. n. 34). 


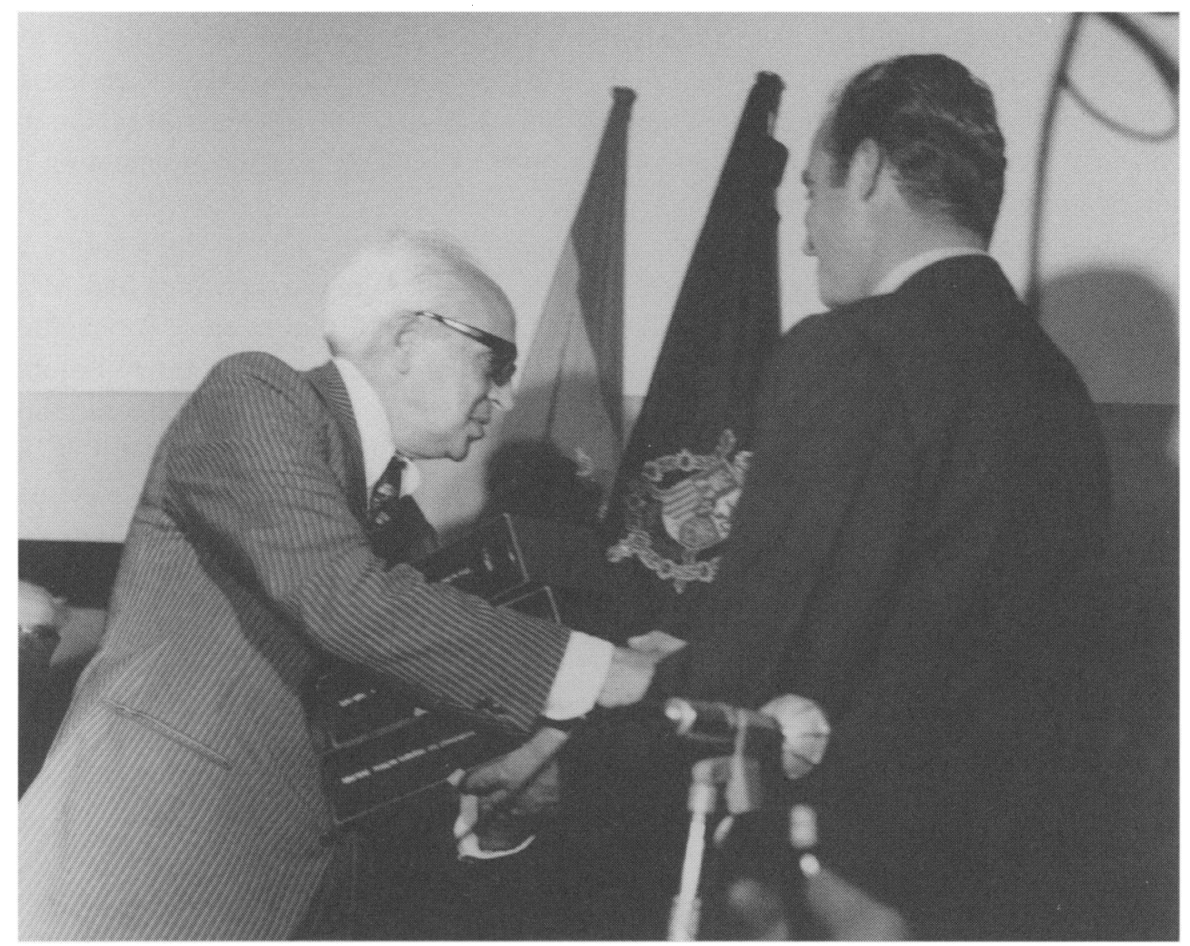

Figure 4. Ochoa receiving the first three volumes of his collected works from Juan Carlos de Borbón, then prince of Spain (and now king), at the ceremony inaugurating the Centro de Biología Molecular, 26 September 1975. Courtesy of the Centro de Biología Molecular, Madrid.

recognized as within the domain of molecular biology, and enzyme research offered experimental validation of the hypothesis derived from DNA structure: that genetic information is transmitted from nucleic acids to proteins. ${ }^{64}$ As a consequence, a renaming of biochemists' concerns and research fields took place, and some of them adopted the term "molecular biology," suggesting that no apparent difference existed between the latter and biochemistry ${ }^{65}$ Some biochemists, concluding that no real differences existed between the two fields, reoriented the description of their interests and research problems.

Some of the participants in the celebration were close longtime friends of Ochoa. David Nachmansohn and Fritz Lipmann had met him in Meyerhof's laboratory in 1929; Herman Kalckar met him in 1938 at the International Congress of Physiology held in Zurich; Efraim Racker worked next door at the NYU medical school; Ernst Chain knew him in Oxford

${ }^{64}$ See, e.g., Judson, Eighth Day of Creation (cit. n. 1); and Charles Yanofsky, "The Search for the Structural Relationship between Gene and Enzyme," in Reflections on Biochemistry, ed. Kornberg et al., pp. 263-271, on p. 267: "By the early 1960s the Watson-Crick model of DNA was widely accepted and generally interpreted in terms of linear correspondence of gene structure and protein structure. Nevertheless, it was essential to provide the experimental verification for so fundamental a concept. I remember presenting rather shyly a brief report at the Cold Spring Harbor Symposium of 1963 . . o of our findings demonstrating colinearity of gene structure and protein structure."

${ }^{65}$ Ochoa himself used the term "molecular biology" to name the new institute that was to be created in Madrid. On the term see the contributions to Chadarevian and Gaudilliére, eds., Tools of the Discipline (cit. n. 1); and Rheinberger, Toward a History of Epistemic Things (cit. n. 1). 
in 1937; and Francisco Grande, Bernard Horecker, and Luis Leloir shared his scientific interests and remained in touch throughout their lives. Others were more recent acquaintances: after his retirement as chairman of the NYU Department of Biochemistry in 1974 he met Sidney Udenfriend and Herbert Weissbach at the Roche Institute of Molecular Biology. Irwin C. Gunsalus, Sarah Ratner, Arthur Kornberg, and Earl A. Stadtman had been colleagues in Ochoa's laboratory at NYU; while Yoshito Kaziro, Charles Gilvarg, E. C. Slater, Eladio Viñuela, Margarita Salas, Peter Lengyel, and Joe Speyer were his former research fellows. ${ }^{66}$

Marianne Grunberg-Manago, Ochoa's chief collaborator in the discovery of PNPase, is conspicuously absent from the list of contributors. What information we have suggests that her name did not come up during the preparatory discussions. But there are other omissions as well. Science policy issues and scientific organizations were not mentioned either. From 1961 to 1967 Ochoa had chaired the International Union of Biochemistry; one of the invited speakers, E. C. Slater, was treasurer of that body at the time of Ochoa's seventieth birthday celebration - but he made no mention of it in his talk. ${ }^{67}$ The cognitive approach adopted for the symposium excluded nonscientific matters - though such an emphasis could only have enhanced recognition of Ochoa's leadership and importance.

The symposium paid tribute not to a single discovery but to Ochoa's entire scientific career. Enzymology was emphasized-both in Ochoa's original research and as an important tool for later lines of work. For example, polynucleotide phosphorylase was acknowledged both as an important enzymological achievement and because it became a tool for elucidating the genetic code. Viewed retrospectively, Ochoa's scientific achievements - from the physiological chemistry of muscle contraction to his work on the genetic code-led him to the core of biochemistry and then on to molecular biology, a trajectory epitomizing the historically central role of enzymology in contemporary biomedical sciences. The symposium for Ochoa should be viewed as an episode in the ongoing debate between biochemists and molecular biologists as to the roles of their respective disciplines in the development of contemporary biology, a debate that was exacerbated in 1961, when Nirenberg presented his first results on deciphering the genetic code. From the earliest days of their discipline, the approach of the self-described molecular biologists was marked by theories or hypotheses whose verification relied on biochemical labor-or so the biochemists thought. This representation at the symposium fails to make it clear, however, that Ochoa had not contributed to the beginnings of molecular biology: enzymologists were not "members of the club" of molecular genetics, nor were they much concerned with the regulation of biological processes. ${ }^{68}$ The transition from mammalian to microbial systems represents in part the transition from physiology to biochemistry. Ochoa emerged as a successful heir of the German physiological tradition in which his initial interest in bioenergetics developed. ${ }^{69}$

${ }^{66}$ See Kornberg et al., eds., Reflections on Biochemistry.

${ }^{67}$ On the IUB see E. C. Slater, "The Uncertain Birthday of the IUB," Trends in Biochemical Sciences, July 1980, pp. vii-viii. Ochoa dedicated the final pages of his autobiography to the IUB; see Ochoa, "Pursuit of a Hobby" (cit. n. 10), pp. 28-30.

${ }^{68}$ See Judson, Eighth Day of Creation (cit. n. 1); and Abir-Am, "Politics of Macromolecules" (cit. n. 1). On the relationship between biochemists and molecular biologists see Chadarevian and Gaudilliére, eds., Tools of the Discipline (cit. n. 1). On metabolic regulation see Angela N. H. Creager and Jean-Paul Gaudilliére, "Meanings in Search of Experiments and Vice Versa: The Invention of Allosteric Regulation in Paris and Berkeley (19561967)," Hist. Stud. Phys. Biol. Sci., 1996, 27:1-89; and Frederic L. Holmes, "Life Cycles: The Regulation of Intermediary Metabolism" (unpublished MS).

69 "Scientifically there was a profound change in Meyerhof's laboratory. When I left it in 1930 it was basically 
Scientific practice and discourse took on an added social dimention in the mid 1970s, as biomedical scientists became concerned about the social implications of recent developments in genetic engineering. The Asilomar Conference held in Pacific Grove, California, in February 1975 "proved to be a pivotal event" in the history of science policy regarding recombinant DNA technology. Geneticists, biochemists, and molecular biologists shared this concern. One of them, Paul Berg, who chaired the Asilomar Conference, also participated in Ochoa's celebratory symposium. Berg, who had been trained under Harland Wood, Herman Kalckar, and Arthur Kornberg, was a pioneer in genetic manipulation using restriction enzymes: "Now enzymes provide the geneticist with surgical tools, scalpels and sutures, to dissect and reconstruct genetic assemblies!'70

Within the national context, Severo Ochoa was a prominent figure who helped to legitimate Spanish scientists' efforts to gain resources and recognition for their research in biochemistry and molecular biology. The symposium not only represented agreement as to Ochoa's role in the development of these fields but also served as an impetus to additional work and support. Two generations of biochemists and one of molecular biologists - some of whom contributed to the celebration-were already engaged in research at Spanish universities or institutes belonging to the CSIC after being trained abroad. Both Ochoa and Juan Oró were actively promoting the biological sciences in Spain through their participation in projects for two new institutes: the Centro de Biología Molecular in Madrid and the Instituto de Biología Fundamental in Barcelona. And yet another special meeting of Spanish biochemists and molecular biologists, at the Fundación Juan March building on 29 September, was scheduled as part of the homage to Ochoa; the participants were Spanish scientists not included among the speakers at the international symposium. ${ }^{71}$

The Spanish contributors to the international symposium represented the scientific leaders whose work helped to establish biochemistry and molecular biology in the country: Alberto Sols, Manuel Losada, Julio Rodríguez Villanueva, Rafael Sentandreu (Rodríguez Villanueva's research fellow), David Vázquez, Margarita Salas, and Eladio Viñuela. Their importance rested on efforts, begun in the late 1950s, that led to the creation of the Sociedad Española de Bioquímica in 1963, to the founding of new departments or sections at the universities and the CSIC, and to the establishment of the two institutes in the 1970s. From the mid 1960s until the mid 1970s, little in the way of Spanish funding was available for their research work; in many cases grants-in-aid from the U.S. National Institutes of Health were crucial for research in biochemistry and molecular biology in Spain. All of the Spanish contributors except for Sentandreu and Rodríguez Villanueva obtained at least one three-year grant from the NIH during the 1960s and early 1970s. Salas and Viñuela were supported by the Jane Coffin Child Memorial Fund, on whose advisory board Ochoa

a physiological laboratory; one could see muscles twitching everywhere. In 1936 it was a biochemistry laboratory. Glycolysis and fermentation in muscle or yeast extracts or partial reactions of these processes catalyzed by purified enzymes, were the main subject of study": Ochoa, "Pursuit of a Hobby" (cit. n. 10), pp. 8 (quotation; emphasis added), 6. See also Kohler, From Medical Chemistry to Biochemistry (cit. n. 7), Ch. 2.

${ }^{70}$ Wright, Molecular Politics (cit. n. 1), esp. Ch. 3; and Paul Berg, "From Enzyme Chemistry to Genetic Manipulation," in Reflections on Biochemistry, ed. Kornberg et al., pp. 253-261.

${ }^{71}$ On the meeting at the Fundación Juan March building see Luis Cornudella, C. F. de Heredia, Juan Oró, and Alberto Sols, Avances de la bioquímica (Barcelona: Salvat, 1977), particularly the preface by the editors ( $\mathrm{p}$. xiii) and the introduction, which quotes the director of the foundation ( $\mathrm{pp} . \mathrm{xv}-\mathrm{xvi}$ ). Ochoa published a history of the Centro de Biología Molecular: Severo Ochoa, "El Centro de Biología Molecular: Los primeros años," Abc, 5 Mar. 1988; and "El Centro de Biología Molecular: Los años creadores," ibid., 12 Mar. 1988. See also his comments in "El Centro de Biología Molecular: Un presente imperdonable," ibid., 23 Mar. 1988. On the background of Spanish biochemists and molecular biologists see Santesmases and Muñoz, "Scientific Organizations in Spain." 
served, when they returned to Madrid after their postdoctoral training in the United States. Each of these Spanish scientists had a personal relationship with Ochoa; in addition, they facilitated and supported the establishment of modern biology in Spain by organizing national congresses and participating in the design process and negotiations that led to the founding of the new research institute in Madrid..$^{72}$

The contributors to the symposium represented an elite community spread throughout the world, from Berkeley to Harvard; from Columbia, Illinois, Kansas, Cornell, Stanford, and Yale to the NIH; from Oxford and Cambridge to the Max Planck and Karolinska Institutes and the University of Zurich. Although internationally respected, the Spanish contributors were not, like most of the others, members of the scientific core within biomedical research. Instead, they might well be regarded as agents for the active dissemination of the knowledge and values of that core group into Spanish academia. In 1975 they were already part of the biochemistry and molecular biology "establishment" in Spain; in a sort of Matthew effect, their participation in a celebratory symposium that highlighted both Ochoa's international importance and his powerful influence on Spanish science brought them additional recognition and further legitimated their leadership roles.

\section{CONCLUSION}

Ochoa shaped the establishment of biochemistry and molecular biology in Spain by encouraging certain conceptual aspects of research in biochemistry and by forging the social connections necessary to obtain academic support for the discipline. He was not the lone international connection; Spanish scientists interested in the new fields themselves established links with other researchers during their postdoctoral training periods abroad. These connections enabled them to publish in peer-reviewed international journals and involved them in the work of international meetings and societies. Nonetheless, Ochoa's scientific authority and prestige were instrumental. His influence, both direct and indirect, advanced the introduction of biochemical research in Spain through several stages; at each, political and institutional constraints were key.

At the end of the 1950s, in the second decade of the Franco dictatorship, Spain revived its scientific research by enabling a small group of young experimentalists to study abroad: as they became familiar with biochemistry and molecular biology as they were practiced in other parts of the world, their own research approaches changed. But they were able to have an effect at home - through the establishment of these disciplines in the research and training structures of Spanish science - only within the framework of the national political context.

After 1959, the young community of Spanish biochemists took advantage of Ochoa's Nobel Prize award. In the protective shadow of the recognition he won, they were able to stress the role of biochemistry in research and teaching and to claim an academic space for themselves apart from established disciplines whose authorities were, they believed, unwilling or unable to appreciate the new contributions. Just as important to the influence of Ochoa was the prevailing nationalistic spirit of early Francoism. Press policies and censorship practices both favored presentations that focused on the distinguished recognition afforded by the Nobel award. Only a few public accounts mentioned that Ochoa had pursued his scientific career in the United States, a focus that would have raised

\footnotetext{
${ }^{72}$ Santesmases and Muñoz, "Scientific Organizations in Spain"; Santesmases and Muñoz, "Scientific Periphery in Spain" (cit. n. 2); and "Instituto de Biología Molecular" [printed in 1973 to present the project], Ochoa Papers.
} 
uncomfortable questions about budgetary and political support for Spanish science. By insisting that he could have won a Nobel Prize even had he remained in Spain, popular accounts stressed nature over nurture. This perspective also suited the official discourse that emphasized Spanish national capability in general and aptitude for science in particular.

As the new generation of scientific researchers consolidated their resources, they joined to create their own society for biochemistry. They emphasized their indebtedness to Ochoa; at the same time, they celebrated the international recognition he had won as a core member of the enzymological community. Yet in 1963, the year the Sociedad Española de Bioquímica was formed, Ochoa himself was very much engaged in molecular biology. The meeting organizers, probably unaware of the direction of his recent work, again focused on his contribution to metabolic (biochemical) topics.

At the time of the sixth FEBS meeting in 1969 Ochoa was deeply involved in molecular biological research pertaining to protein synthesis and the decoding of DNA as information. The field of molecular biology was thus in a position to benefit from changing circumstances in Spain: the projects for institutes of molecular biology in Barcelona and Madrid, established as part of the 1970 agreement between Spain and United States, were among the fruits of these developments. Ochoa's work on protein synthesis, one of the main topics of the FEBS meeting, was treated in a three-session symposium with contributions by three Spanish scientists. Even so, enzymes retained a central role: two symposia and a colloquium were devoted to enzymological topics.

As Ochoa approached his seventieth birthday, enzymes remained at the core of his work. The debate between biochemists and the first self-described molecular biologists and structuralists reflects how knowledge develops: previous knowledge eventually becomes a tool for some scientists but continues to define disciplines for others. Enzymes were tools for molecular biology, but they remained essential objects of inquiry for biochemists, who considered them vital for further research - as the contributors to Ochoa's birthday symposium showed. Ochoa's transition from biochemistry to molecular biology may well explain the smooth introduction of molecular biology into Spain, which took place under his influence. The ceremonies celebrating Ochoa's seventieth birthday, held in Barcelona and Madrid in 1975, focused on aspects of his scientific career from physiology to microbiology; biochemical issues were once again a focus, as the invited speakers fixed on enzymology as the central subject in Ochoa's lifelong work. This perspective connected the 1975 symposium to other recent debates and to celebrations of other chemists, at a time when the central role of molecular biology was being acknowledged in settings like the Asilomar Conference on the social implications of genetic engineering.

It would be too simplistic to assign Ochoa the main role in the establishment of biochemistry and molecular biology in Spain; it would also be a mistake to overlook his importance. National circumstances were influential indeed. As time passed, the growing Spanish community of biochemists and molecular biologists was very ready - and increasingly able - to draw on Ochoa's leadership and example whenever national conditions seemed to offer an opportunity to improve the situation of their disciplines. 